\title{
Kriptopara Dinamikleri: Bitcoin Cash, Ethereum, Litecoin ve Ripple
}

\author{
Cryptocurrency Dynamics: Bitcoin Cash, Ethereum, Litecoin and Ripple
}

\begin{abstract}
Cem Çağrı DÖNMEZ ${ }^{1}$ iD, Doruk ŞEN² ${ }^{\text {iD }}$, Umut HAZIR ${ }^{3}$ (D)
${ }^{1,3}$ Marmara Üniversitesi, Endüstri Mühendisliği Bölümü, 34722, İstanbul, Türkiye

2 İstanbul Bilgi Üniversitesi, Endüstri Mühendisliği Bölümü, 34060, İstanbul, Türkiye

Öz

Bu makalenin amacı kriptopara birimleri olarak da adlandırılan merkezi olmayan para birimleri olan Bitcoin Cash, Ethereum, Litecoin ve Ripple arasındaki ilişkilerin ortaya çıkarılmasıdır. Çalışmada üzerinde çalışılan dönem 03.08.2017 - 17.03.2020 tarihleri arasıdır. Çalışmada birim kök testi olarak Augmented Dickey-Fuller (ADF) testi uygulanarak serilerin durağan olduğu düzeyler saptanmış ve aralarındaki nedensellik ilişkisi Granger nedensellik testi ile sınanmıştır. Seriler arasındaki ilişkilerin yönü ve büyüklüğü, vektör otoregresif (VAR) model tekniğiyle belirlenmeye çalışılmıştır. Ayrıca, etki-tepki analizleri ve varyans ayrıştırma analizleri yapılarak serilerin standart sapmasında meydana gelen değişimin dönem bazında \% kaçının diğer değişkenler tarafından açıklandığı ortaya konmuştur.
\end{abstract}

Anahtar Kelimeler: ADF Birim Kök Testi, VAR Analizi, Nedensellik Analizi, Kriptopara.

\begin{abstract}
The purpose of this article is to reveal the relationships between Bitcoin Cash, Ethereum, Litecoin and Ripple, which are decentralized currencies, also called cryptocurrencies. The period worked on within the scope of the study is between 03.08.2017-17.03.2020. In the study, the stationary levels of the series were determined by applying the Augmented DickeyFuller (ADF) test as a unit root test, and the causality relationship between them was tested with the Granger causality test. The direction and size of the relationships between them were tried to be determined by the vector autoregressive (VAR) model technique. In addition, by performing impact-response analysis and variance decomposition analysis, it was revealed that what $\%$ of the change in the standard deviation of the series was explained by other variables on a period basis.
\end{abstract}

Keywords: ADF Unit Root Test, VAR Analysis, Causality Analysis, Cryptocurrency.

\section{GíRiș}

Para, ekonomik sistemler içerisinde önemli bir yere sahip olan bir dönüşüm aracıdır. Ekonomik sistemler içerisinde yerinin doldurulması oldukça güç olan bu değişim aracı, işletmeler ve ülkelerin rekabet ortamında diğer ülkelere fark yaratması başka bir ifade ile üstünlük kurabilmesi bakımından çok daha önemli bir yere sahiptir. Küreselleşme süreci ve bilgi toplumuna geçişle birlikte teknolojinin üretimde yaygın olarak kullanılmaya başlanması dünya üzerinde pek çok olguyu değişime sürüklemiştir (Ulusoy,2011). Bu değişim süreci beraberinde bir dijitalleşme ortamı yaratmıştır. Dijital dönüşümle birlikte dijital teknolojinin olanaklarından tam olarak yararlanmak için ticari faaliyetler, süreçler, ürünler ve modeller de değişime uğramıştır. İnsanlık tarihinin yeri doldurulması mümkün olmayan en önemli buluşlarından biri olan para da tarih boyunca sürekli değişime uğramıştır. Bu değişim süreci sırasında para olarak kullanılan materyalin değiştiği ama bununla birlikte paranın her daim merkezi bir otorite tarafından kontrol edildiği görülmüştür fakat 2008 yılının son aylarında ortaya çıkan küresel ekonomik krize bir tepki olarak 2009 yılında Satoshi Nakamoto takma adıyla bilinen bir kişi tarafından merkeziyetsiz bir para birimi olan Bitcoin ortaya atılmış ve arkasındaki blok zinciri (Türkçe isim olarak kullanılmasını önerdiğimiz; KayıtZinciri) teknolojisi ile Bitcoin, para konseptine benzersiz bir değişiklik kazandırmıştır. Teknolojide yaşanan gelişime paralel olarak para da yaşanan bu yenilikle birlikte basmakalıp çerçevesinden kurtulmuş ve sanal para artık daha çok kullanılır hale gelmiştir. Bitcoin'in öncülüğünde gelişen kriptoparalar günden güne daha çok ilgi uyandırmış ve gelinen son noktada binlerce altcoin projesiyle birlikte sanal paraların piyasa değerlerinde ve günlük işlem hacimlerinde yüksek oranlarda büyüme görülmüştür (2021 y1l itibariyle tüm kriptoparaların toplam piyasa değeri 1 trilyon doların üstündedir).

Geleneksel ekonomide paranın 3 temel işlevi bulunmaktadır. Bu üç temel işlev; paranın değişim aracı, hesap birimi ve tasarruf aracı olarak kullanılmasına bağlanır (Abaan, 1997: 6-7). Geleneksel ekonomide paranın 3 temel fonksiyonundan yatırım ve tasarruf aracı olma özelliğini taşıyan kriptoparaların para olup olmadığı konusunda tartışmalar hala daha devam etmektedir. Merkezi olmayan dağıtılmış bir ağda blok zinciri teknolojisine dayalı olan dijital paraların yasal bir düzenlemeye tabi olmaması ve arkasında onu kontrol eden bir devlet otoritesinin bulunmaması kriptoparaları geleneksel paralardan ayıran en önemli özellikler olarak ön plana çıkmaktadır. 
Merkezi olmayan kriptoparalara son yillarda bireysel ve kurumsal yatırımcıların büyük ilgi duyduğu görülmektedir. $\mathrm{Bu}$ nedenle kriptopara birimleri arasındaki etkileşim, yatırımcı açısından büyük önem arz eden bir konuya dönüşmüştür.

Çalışmanın amacı, yatırım aracı olarak da adlandırılan finansal değişkenler; Bitcoin Cash, Ethereum, Litecoin ve Ripple arasındaki ilişkilerin ortaya çıkarılmasıdır. $\mathrm{Bu}$ amaçla VAR ve nedensellik analizi yapılmaktadır.

Beş bölüm ihtiva eden bu çalışma giriş bölümüyle başlamaktadır. İkinci bölümde konuyla alakalı daha önce yapılmış olan bilimsel çalışmalara yer verilen literatür bölümü bulunmaktadır. Üçüncü bölümde 03.08.2017-17.03.2020 dönemini kapsayan verilerle Bitcoin Cash, Ethereum, Litecoin ve Ripple kriptopara birimlerinin fiyatlanmaları üzerine birbirlerinin etkilerini tespit etmek amacıyla kullanılan teknikler ve veri kümesi tanıtılmıştır. Bir sonraki bölümde serilere bu teknikler uygulanmış ve bunun neticesinde elde edilen bulgular yorumlanmıştır. Beşinci bölümde ise sonuçlar özetlenmiş ve kriptopara yatırımcılarına tavsiyeler verilerek çalışma bitirilmiştir.

\section{LITERATÜR TARAMASI}

2017 yılında yaşanan ekonomik krize bir tepki niteliğinde ortaya çıkan Bitcoin ile para, dijital bir dönüşüme uğramıştır. $\mathrm{O}$ günden bugüne artan ilgi ve piyasaya sürülen yeni altcoinler ile kriptoparaların market hacmi sürekli büyümüş ve bugün azımsanamayacak bir hale gelmiştir. Dolayısıyla bu artan ilgi, kriptoparalar ile alakalı akademik çalışmaların yapılmasına zemin hazırlamıştır. $\mathrm{Bu}$ bağlamda Briere vd. (2015), çalışmalarında Bitcoin'i bir plasman aracı olarak incelemişlerdir. Araştırmalarının sonucunda, Bitcoin'in yüksek getiri ve oynaklığının yanı sıra geleneksel varlıklarla düşük korelasyonu nedeniyle, çeşitlendirilmiş bir portföy için önemli faydalar sağladığına ulaşmışlardır. Ancak uzun vadede bazı risklerin ortaya çıkabileceğini de eklemiş̧lerdir. Kajtazi ve Moro (2017) ise Bitcoin, portföy çeşitlendirme ve Çin finansmanı pazarlar üzerine çalışmışlardır. Çalışmalarının sonucunda, Bitcoin ile özellikle batı ülkelerinde işlem gören geleneksel varlıklar arasında önemli bir korelasyon veya negatif korelasyon görülmezken, Bitcoin ile birkaç Çin varlığı arasında küçük ama istatistiksel olarak önemli korelasyonların var olduğu sonucuna ulaşmışlardır.

Atik vd. (2015), çalışmalarında dünyada en çok tercih edilen bazı yerel para birimleri ile Bitcoin arasındaki fiyat ilişkisini incelemek için Granger nedensellik testini kullanmışlardır. Çalışmanın sonucu olarak Japon Yeni'nden Bitcoin'e doğru tek yönlü bir nedensellik ilişkisinin olduğu sonucuna ulaşmışlardır. Baur vd. (2017) çalışmalarında, Bitcoin'in volatilitesi üzerine derinlemesine bir analiz gerçekleştirmişlerdir. Çalışma kapsamında Granger nedensellik testi kullanmışlardır.
Çalışmanın sonucunda, Bitcoin'in fiyatındaki oynaklığın ana para birimlerine (ABD doları, Euro ve yen) kıyasla 30 kat daha fazla olduğunu ve bu sebeple Bitcoin'in bir para birimi olarak işlev göremeyeceğini ortaya koymuşlardır. İçellioğlu ve Öztürk (2017) çalışmalarında, Bitcoin ile dünya üzerinde en çok kullanımı olan dolar, euro vb. dövizler arasındaki kısa ve uzun periyotlu nedensellik ilişkisini incelemek için 2013-2017 tarihleri arasındaki verileri kullanmışlardır. Bitcoin'in dolar, euro vb. dövizler ile olan kısa ve uzun dönemli nedensellik ilişkisinin analizi için Johansen ve Granger nedensellik testlerini kullanmışlardır. Çalışmanın sonucunda Bitcoin ile seçilen dövizler arasında kısa ve uzun vadeli bir ilişkinin saptanamadığını belirtmişlerdir. Benzer bir çalışma olarak Çakın (2019), araştırmasında Bitcoin, döviz kurları ve alternatif kriptoparalar arasındaki ilişkiyi incelemiştir. Araştırma kapsamında korelasyon testi ve Granger nedensellik testleri uygulamıştır. Araştırmanın sonucunda, Bitcoin'in alternatif kriptoparalarla pozitif ve güçlü bir korelasyon ilişkisi olduğu saptanmıştır.

Kriptoparaların birbirleri ile bağlantısını irdelemeye yönelik bazı faaliyetler gerçekleştirilmiştir. Bu faaliyetlerden; Ciaian vd. (2018) yapmış oldukları çalışmada kriptopara piyasasında işlem hacmi en yüksek olan Bitcoin dahil 17 kriptopara biriminin fiyatları arasındaki ilişkiyi kısa ve uzun vadede ayrı ayrı incelemişlerdir. Çalışma kapsamında analize dahil edilen 17 adet kriptoparanın 2013-2016 y1lları arasındaki döneme ait günlük kapanış değerleri kullanılmıştır. Çalışmanın sonucunda Bitcoinin ve çalışmada kullanılan diğer tüm altcoinlerin fiyatlanması arasında hem uzun dönemde hem de kısa dönemde bir bağlantının var olduğu ve bu bağlantının kısa dönemde uzun döneme göre çok daha etkili olduğu sonucuna varılmıştır. Aynı amaçla Konuşkan vd. (2019) tarafindan yapılan çalışmada 01.01.201831.12.2018 tarihleri arasında kriptoparaların günlük kapanış değerleri dikkate alınarak aralarındaki fiyat ilişkisini analiz etmişlerdir. $\mathrm{Bu}$ amaçla serilere birim kök testi, Johansen eşbütünleşme testi ve nedensellik analizi testleri uygulamışlardır. Çalışmanın sonucunda, değişkenlerin uzun dönemli anlamlı bir ilişki içerisinde olduğu sonucuna ulaşılmıştır. Ayrıca, Bitcoin ile Ethereum ve Ripple arasında istatistiki olarak anlamlı bir nedensellik ilişkisi olduğu sonucuna varılmıştır.

Kripto markette piyasa değeri en fazla olan kriptoparaların birbirleri üzerindeki etkilerini incelemeye yönelik çalışmalar yapılmıştır. Çeker (2018), çalışmasında kriptoparalar ve ekonomik etkileri üzerine araştırmalar yapmıştır. Çalışma kapsamında piyasa değeri en yüksek olan kriptopara birimleri olan Bitcoin, Ethereum ve Ripple'ın işlem hacmi ve birim fiyat değişimleri karşılaştırılmıştır. Ayrıca Bitcoin ile ticaret hacmi yüksek resmi paraların etkileşimi incelenmiştir. Araştırma sonucunda, her üç kriptopara biriminin işlem hacimlerinin ve birim fiyat değişimlerinin benzer şekilde gerçekleştiği 
gözlemlenmiştir. Her ne kadar ufak değişiklikler olsa da kriptoparaların eş emeller ile arz edildiği neticesine varılmıştır. Bitcoin ile ticaret hacmi yükek resmi paraların etkileşiminin incelenmesinde ise sadece Japon Yeni ve Bitcoin arasında ilişkinin olduğu saptanmış ve bunun Japonya'nın yasal düzenlemelerle kriptoparalara finansal piyasalarda yer vermesiyle bu etkileşimin başladığına ulaşılmıştır. Aynı şekilde; Temizer ve Serbestoğlu (2018), araştırmalarında Bitcoin, Ripple, Litecoin ve Ethereum olmak üzere işlem hacmi olarak ilk beşte yer alan kriptopara birimlerine yer vermişlerdir. 7 Haziran 2015 ile 12 Şubat 2018 tarihleri arasındaki dolar cinsinden kapanış değerlerini veri seti olarak kullanmışlardır. Seriler arasındaki dinamik ilişkinin tespitine yönelik yapılan çalışmada VAR modeline dayalı Grander nedensellik testini uygulamışlardır.

Sonuç olarak, Bitcoin ve Ethereum'da getiriden işlem hacmine doğru tek yönlü, Ripple ve Litecoin'de ise hem getiriden işlem hacmine hem de işlem hacminden getiriye doğru çift yönlü bir nedensellik ilişkisinin var olduğuna ulaşmışlardır. Yine; Karaağaç ve Altınırmak (2018), çalışmalarında birçok kriptopara borsasında işlem görmekte olan BTC, ETH, XRP, BCH, ADA, LTC, NEM, NEO, XLM ve IOTA gibi piyasa değeri en yüksek kriptoparaların fiyat oluşumlarında birbirleri üzerindeki etkilerini araştırmışlardır. Çalışma kapsamında, verilerin Aralık 2017 ile Ocak 2018 tarihleri arasındaki günlük kapanış değerlerine Johansen eş bütünleşme testi ve Granger nedensellik testi uygulayarak bu verilerin fiyat hareketleri arasındaki ilişkiyi ortaya koymaya çalışmışlardır.

Karaoğlan vd. (2018), araştırmalarında ana teması kriptopara piyasası olacak şekilde ülkemizde hem halkın kriptoparalara olan bakış açısını ve farkındalığını değerlendirmek hem de kriptoparayla ödeme alan işletmelerin güdüleri üzerine iki aşamadan oluşan bir çalışma yapmışlardır. İlk aşamada amaç; gelişmekte olan ve bilgi toplumu olma yolunda ilerleyen ülkemizde, toplumsal anlamda kriptoparaların bilinirliği ve halkın kriptopara piyasasına karşı olan tutumunu ölçmek olmuştur. İkinci aşamadaki amaç; günümüz liberal ekonomisinin belirleyici unsurlarından birisi olan işletmelerden kriptopara birimlerini ticari faaliyetlerinde kullananlarla çevrimiçi mülakat yapılarak motivasyonlarını incelemek olmuştur. Çalışmanın neticesinde, kriptoparalara karş1 nesnel farkındalık ölçülerek, bu farkındalığın kripto para dünyasına karşı davranış ile kriptopara kullanımı teşvikine yönelik yapılan pazarlama faaliyetlerinin tüketiciler üzerindeki tesirine yönelik yapılacak bir çalışmanın şirketlere yol gösterici nitelikte olabileceği sonucuna varılmıştır.

\section{METODOLOJI}

\subsection{Veri Seti}

Bir yatırım aracı olarak kullanılan kriptoparalar arasındaki fiyat ilişkisi ve bu ilişkinin seyri ve büyüklüğü, yatırımcılara yön verebilecek özelliklerdir. $\mathrm{Bu}$ nedenle bu çalışma 2017:03-2020:1 dönemleri arasında Bitcoin Cash (BCH), Ethereum (ETH), Litecoin (LTC) ve Ripple (XRP) kapanış fiyatları (USD) araasındaki ilişkiyi ortaya koymayı amaçlamaktadır. Çalışmada aylık veriler kullanılmış olup veriler (https://coinmarketcap.com/) sitesinin veritabanından alınmıştır. Şekil.1.'de sırasıyla Bitcoin Cash, Ethereum, Litecoin ve Ripple değişkenlerinin aylık değerlerinin çalışma dönemleri boyunca seyrini gösteren grafik yer almaktadır.
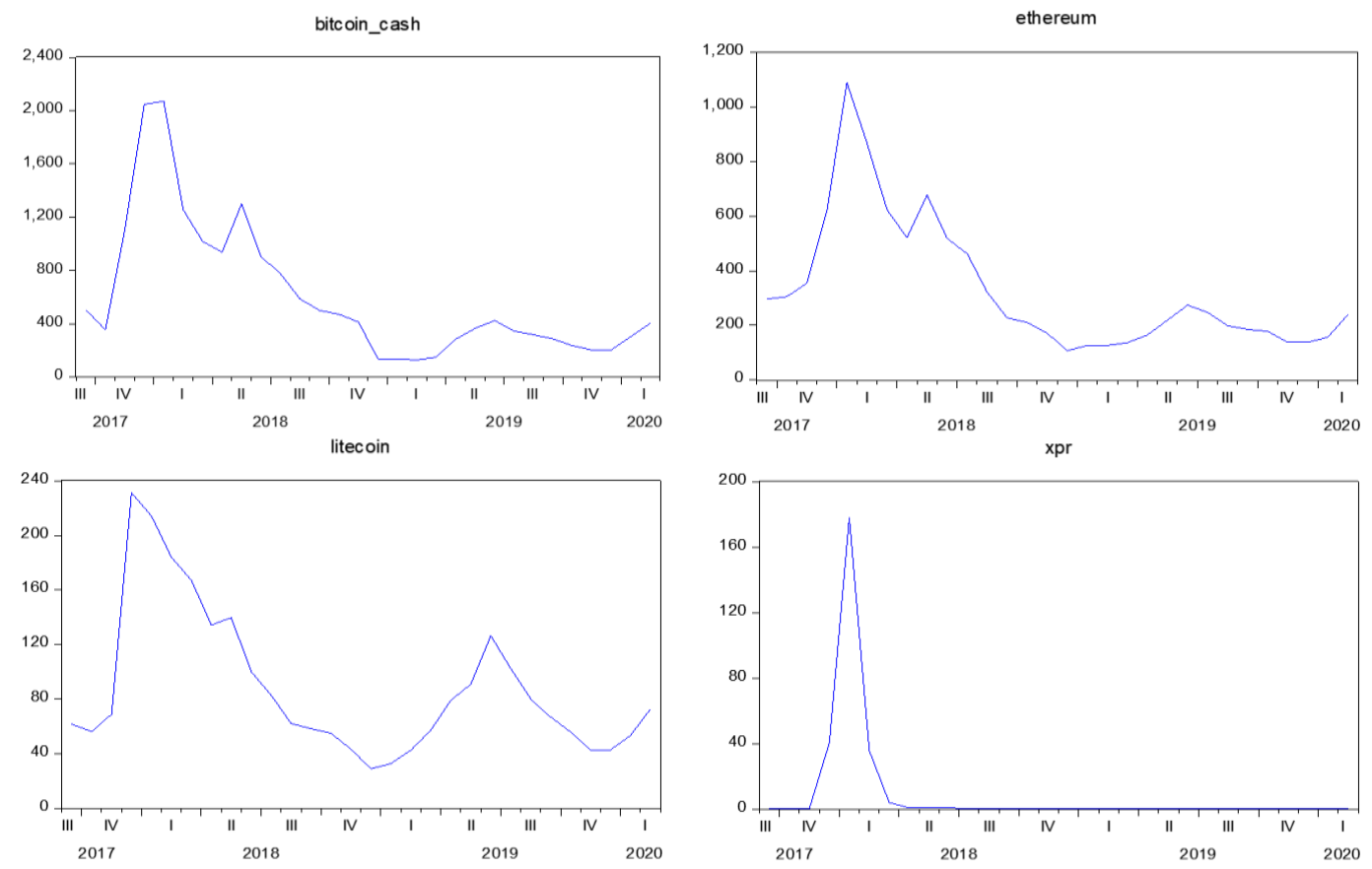

Şekil.1. Çalışmada kullanılan kriptoparaların seçilen dönemlerdeki fiyat grafiğgi 


\subsection{Kullanılan Teknikler}

Çalışmada ilk olarak değişkenlerin durağanlıkları Augmented Dickey-Fuller (ADF) testi ile belirlenmekte ve test sonuçlarına göre serilerin durağanlığını sağlayacak dönüşümler yapılmaktadır. Serilerin durağan olduğu düzeyler saptandıktan sonra bu dört seri ayrı ayrı analiz edilmekte; değişkenler arasındaki ilişkinin yapısı etki-tepki fonksiyonları ve serilere verilen bir birimlik şokun, VAR modelindeki değişkenleri etkilemedeki oransal olarak büyüklüğü varyans ayrıştırması ile ortaya konarken değişkenler arasındaki ilişkinin yönü ise Granger nedensellik analizi ile tahmin edilmektedir.

Aşağıda kullanılacak testler ve izlenecek yöntemler hakkında bilgiler verilmektedir.

\subsubsection{Durağanlık Analizi}

Zaman serisi analiziyle oluşturulan ekonometrik modeller durağan seriler için oluşturulmalıdır. Aksi takdirde, durağan olmayan serilerle tahmin edilen ekonometrik modellerde sahte regresyon ilişkisi ortaya çıkmaktadır. Bu durumda, t ve f sınama değerleri geçerliliğini kaybettiğinden bulgular gerçek ilişkiyi yansitmaz. Bu sebeple, durağan olmayan zaman serileriyle yapılan regresyon analizinin anlaml olabilmesi ve gerçek ilişkileri yansıtabilmesi ancak ve ancak durağan olmayan zaman serileri arasında bir eş bütünleşme ilişkisinin var olmasıyla mümkün olmaktadır. Bu nedenle, analizlerin uygulanabilmesinin ilk şartı olan durağanlık analizinin incelenmesi gerekir. Bir zaman serisinin durağan olabilmesi için ortalama, varyans ve kovaryansının zaman içinde değişkenlik göstermemesi ve iki dönem arasındaki kovaryansının, bu kovaryansın hesaplandığı döneme değil de yalnızca iki dönem arasındaki uzaklığa bağlı olması gerekir (Guajarati, 2003: 817-818).

Zaman serilerinin durağanlıkları Augmented DickeyFuller (ADF), Phillips-Perron (PP), KPSS gibi birçok test ile sınanmaktadır. Bu çalışmada değişkenlere ait serilerin durağanlık araştırması için Augmented Dickey-Fuller (ADF) birim kök testi yapılmıştır. $Y_{t}$ serilerinin birim kök özelliğini test etmek için aşağıdaki Augmented Dickey-Fuller (ADF) regresyon denklemi kullanılır:

$$
\Delta Y_{t}=\alpha_{0}+\alpha_{1} t+\delta Y_{t-1}+\sum_{i=1}^{N} \Psi \Delta Y_{t-i}+\varepsilon_{t}
$$

Yukarıdaki denklemde $\Delta$ birinci fark işlemcisini; $\mathrm{t}$ bir zaman trendini, $\varepsilon_{t}$ ortalaması sıfir, kendi gecikmeli değerleriyle olan kovaryansları sıfir ve varyansları sabit, normal dağılıma sahip, rassal hata terimini; $Y_{t}$ kullanılan serileri ve $\mathrm{N}$ ise hata terimlerinin $\operatorname{ard}{ }_{1 s ̧ 1 \mathrm{k}}$ bağımlılığını gidermek için Akaike Bilgi Kriteri tarafından belirlenen bağımlı değişkenin gecikme uzunluğunu ifade etmektedir. ADF testinin hipotezleri: $H_{0}$ : Seri durağan değildir (Birim kök vardır)

$H_{a}$ : Seri durağandır şeklindedir.
Test, deterministtik öğelerle ilgilenmeyip sadece birim köke odaklanır ve sıfır hipotezinin reddedilmesi, $Y_{t}$ değişkeninin durağan olduğunu gösterir. Bu durum $Y_{t}$ $\sim \mathrm{I}(0)$ olarak gösterilir.

\subsubsection{Vektör Otoregresyon (VAR) Model}

Sims (1980) tarafından geliştirilen VAR modeli, çoklu zaman serileri arasındaki doğrusal bağımlılıkları sistem bütünlüğü içerisinde kontrol etmek için kullanılan stokastik bir süreç modelidir. VAR modellerinde kullanılan bağımlı ve bağımsız değişkenler arasında içsellik problemleriyle karşı karşıya kalınır (Özgen \& Güloğlu, 2004). Ek olarak modelde yer alan içsel ve dışsal değişkenler arasında kesin bir ayrım söz konusu değildir (Barışık \& Kesikoğlu, 2015). Bir ekonometrik modelde kullanılan değişkenin zaman içinde izlediği yükseliş veya düşüş trendinin sistemdeki bir başka değişkenin trendinden bağımsız olup olmadığı bilinememektedir. Modelin arkasındaki ana düşünce, tüm değişkenleri simetrik olarak ele almaktır, öyle ki, dışsal olduğundan emin olmadığımız değişkenler içsel olarak modellenir. Bu sayede, her bir değişkenin kendi gecikmeli değerleriyle, diğer gecikmeli değişkenlerin şimdiki ve geçmiş değerleriyle açıklanabildiği $n$ değişkenli ve $\mathrm{n}$ denklemli doğrusal bir model oluşturulur.

İki değişkenli VAR modeli standart haliyle aşağıdaki gibi ifade edilebilir:

$$
\begin{aligned}
& y_{t}=a_{1}+\sum_{i=1}^{p} b_{1 i} y_{t-i}+\sum_{i=1}^{p} b_{2 i} x_{t-i}+\varepsilon_{1 t} \\
& x_{t}=c_{1}+\sum_{i=1}^{p} d_{1 i} y_{t-i}+\sum_{i=1}^{p} d_{2 i} x_{t-i}+\varepsilon_{2 t}
\end{aligned}
$$

Yukarıda belirtilen iki değişkenli VAR modelinde, (p) gecikmelerin uzunluğunu, $(\varepsilon)$ ise ortalaması sıfır, kendi gecikmeli değerleriyle olan kovaryansları sifir ve varyansları sabit, normal dağılıma sahip, rassal hata terimlerini temsil etmektedir. VAR modelinde hataların kendi gecikmeli değerleriyle ilişkisi olması varsayımı, modele herhangi bir kısıt getirmemektedir. Çünkü değişkenlerin gecikme uzunluğunun arttırılmasıyla otokorelasyon sorununun üstesinden gelinilir.

Modellerde yer verilen $\mathrm{p}$ gecikme uzunluklarının belirlenmesinde ise, LR testi ile FPE, AIC, SC ya da HQ kriterlerinden yararlanılmaktadır. Uygulamada LR testi sonucu, diğer kriterlere göre daha uzun gecikmeler elde edilmektedir. $\mathrm{Bu}$ nedenle çalışmada, cimrilik prensibi izlenerek SC ve AIC kriterleri, gecikmelerin belirlenmesinde temel alınmıştır.

Çalışmada kullanılan değişkenlerin kendi gecikmeli değerleriyle diğer gecikmeli değişkenlerin şimdiki ve geçmiş değerleriyle ifade edilebildiği 4 değişkenli otoregresif model aşağıda gösterilmiştir. 
$\left[\begin{array}{l}B C H \\ E T H \\ L T C \\ X R P\end{array}\right]=\left[\begin{array}{l}C_{1} \\ C_{2} \\ C_{3} \\ C_{4}\end{array}\right]+\left[\begin{array}{llll}\alpha_{11}(L) & \alpha_{12}(L) & \alpha_{13}(L) & \alpha_{14}(L) \\ \alpha_{21}(L) & \alpha_{22}(L) & \alpha_{23}(L) & \alpha_{24}(L) \\ \alpha_{31}(L) & \alpha_{32}(L) & \alpha_{33}(L) & \alpha_{34}(L) \\ \alpha_{41}(L) & \alpha_{42}(L) & \alpha_{43}(L) & \alpha_{44}(L)\end{array}\right]\left[\begin{array}{l}B C H_{t-1} \\ E T H_{t-1} \\ L T C_{t-1} \\ X R P_{t-1}\end{array}\right]+\left[\begin{array}{c}e_{1 t} \\ e_{2 t} \\ e_{3 t} \\ e_{4 t}\end{array}\right]$

Burada; BCH, Bitcoin Cash; ETH, Ethereum; LTC, Litecoin; XRP, Ripple ve C sabit terimler olarak tanımlanmıştır. $e_{1 t}, e_{2 t}, e_{3 t}, e_{4 t}$ ortalaması sıfır ve sabit kovaryansa sahip rastgele stokastik süreçlerdir. Katsayllar matrisindeki $\alpha_{i j}(L)$ terimini ifade etmek gerekirse; alt indisdeki $\mathrm{i}$ denklem numarasını $\mathrm{j}$ ise açıklayıcı değişkeni temsil etmektedir. Örneğin; $\alpha_{34}$ 3.denklem, $L T C_{t}$ ve 4. açıklayıcı değişken $X R P_{t-1}, \mathrm{~L}$ ise gecikme işlemcisidir.

VAR modellerinin parametrelerin yorumlanmasına yönelik olmadığı gibi öngörü amaçlı da olmadığ bilinmektedir. Modelin amacı, değişkenler arasındaki ilişkiyi etki-tepki katsayıları yardımı ile ortaya koymaktır; ancak denklemde değişkenlerin gecikmeli değerleri yer aldığı için öngörüde de başarılı oldukları görülür (Turgan, 2008).

\subsubsection{Granger Nedensellik Analizi}

Ekonometrik çalışmalarda iki ya da daha fazla değişken arasında ilişki olup olmadığının yanı sıra ilişkinin yönü de önem kazanmaktadır. Bu sebeple Granger (1969) tarafından tanıtılan nedensellik kavramı, iki değişken arasındaki neden-sonuç ilişkisini ortaya koymaktadır. VAR modelinde ilişkinin yönüyle ilgilenilmezken, Granger nedensellik testi ilişkinin yönü ile de ilgilenmektedir (Sever \& Demir, 2007). Ayrica, nedensellik analizinde VAR modelinden farklı olarak, bir denklem sistemi söz konusu olmayıp denklemler tek tek ele alınmaktadır. Nedensellik analizi yalnızca kovaryans durağan seriler için yapılabilmektedir. $\mathrm{Bu}$ sebeple serilerin durağan olduğu düzeyler tespit edilmiş ve testlere durağan oldukları düzeyler üzerinden devam edilmiştir.

Nedensellik testi, bağımlı değişkenin, gelecekteki tahmini değerinden, kendisinin ya da bağımsız değişkenlerin geçmiş dönem değerinden etkilenmesine dayanmaktadır. Aynı zamanda sonucun gerçekleşmesi için nedenin gerçekleşme zorunluluğu olduğundan neden ve sonucun gerçekleşmesi arasında bir zaman gecikmesi gerçekleşmektedir. Bu sebeple Granger Nedensellik Testi'ne başlamadan önce bilgi kriterleri kullanılarak model için optimal gecikme uzunlukları belirlenmektedir. $X_{t}$ ve $Y_{t}$ incelenecek değişkenler olduğunda Granger ile nedensellik ilişkisi aşağıdaki model yardımıyla test edilebilir (Granger, 1969: 431).

$$
\begin{aligned}
& Y_{t}=\sum_{i=1}^{n} a_{i} X_{t-i}+\sum_{i=1}^{n} b_{i} Y_{t-i}+\varepsilon_{1 t} \\
& H_{01}=\sum_{i=1}^{n} a_{i}=0 X_{t}, Y_{t}^{\prime} \text { ye neden olmamaktad } \mathrm{r}
\end{aligned}
$$

$H_{a 1}=\sum_{i=1}^{n} a_{i} \neq 0 X_{t}, Y_{t}^{\prime} y e$ neden olmaktad $\iota$

$X_{t}=\sum_{i=1}^{n} c_{i} X_{t-i}+\sum_{i=1}^{n} d_{i} Y_{t-i}+\varepsilon_{2 t}$

$H_{02}=\sum_{i=1}^{n} d_{i}=0 Y_{t}, X_{t}^{\prime}$ ye neden olmamaktadir

$H_{a 2}=\sum_{i=1}^{n} d_{i} \neq 0 Y_{t}, X_{t}^{\prime} y e$ neden olmaktad $\mathrm{r}$

Burada $a_{i}, b_{i}, c_{i}, d_{i}$; gecikme katsayılarını, n; gecikme derecesini ve $\varepsilon_{1 t}, \varepsilon_{2 t}$; aralarında seri korelasyon bulunmayan hata terimlerini göstermektedir. Modellerdeki bağımsız değişkenin gecikmeli değerlerine ait katsayılarının tümünün sıfıra eşit olup olmadığının test edilmesi muhtemel dört durumu oluşturmaktadır. Bunlar;

- $\quad a_{i}$ katsayıları belirli bir anlamlılık düzeyinde sifirdan farklı bulunursa $H_{01}$ hipotezi reddedilir. $X_{t}, Y_{t}$ 'nin Granger nedenidir hipotezi kabul edilir. Burada tek yönlü bir nedensellik söz konusudur.

- $\quad d_{i}$ katsayıları belirli bir anlamlılık düzeyinde sifirdan farklı bulunursa $H_{02}$ hipotezi reddedilir. $Y_{t}, X_{t}$ 'nin Granger nedenidir hipotezi kabul edilir. Burada da nedensellik tek yönlüdür.

- Hem $a_{i}$ hem de $d_{i}$ katsayıları belirli bir anlamlılık düzeyinde sıfirdan farklı bulunursa $H_{01}$ ve $H_{02}$ hipotezleri reddedilir. $X_{t}$ ve $Y_{t}$ arasında çift yönlü bir nedensellik ilişkisinin olduğu anlaşılır.

- Hem $a_{i}$ hem de $d_{i}$ katsayılarının bütün değerleri ancak sifir ise $H_{01}$ ve $H_{02}$ hipotezleri kabul edilir. Bu durumda ise $X_{t}$ ve $Y_{t}$ arasinda nedensellik ilişkisinin olmadığı sonucuna ulaşılır.

\subsubsection{Etki-Tepki Analizi}

Etki-tepki analizi ile modelde bulunan değişkenlerden herhangi birine bir birimlik bir şok uygulandığında hem kendisi hem de diğer değişkenlerin kısa ve uzun vadede bu değişime vermiş olduğu tepkiler gözlemlenmektedir (Enders, 2004: 272-280).

\subsubsection{Varyans Ayrıştırması}

Varyans ayrıştırması, eş zamanlı bir modeldeki her bir içsel değişkende meydana gelen değişimi modelde bulunan tüm içsel değişkenlerin değişimi şeklinde ifade etmektedir. $\mathrm{Bu}$ yönüyle varyans ayrıştırması, tüm sistemin hareketi hakkında bilgi sahibi olmaya olanak sağlamaktadır (Özgen \& Güloğlu, 2004). VAR modelinin hareketli ortalamalar bölümünden elde edilen varyans ayrıştırması, bağımlı değişkendeki değişkenliğin ne kadarının kendi varyansından, ne kadarının diğer değişkenlerin varyansından 
kaynaklandığının belirlenmesini sağlamaktadır. Bir değişkende meydana gelen değişimin büyük bir kısmı kendisindeki şoklardan kaynaklanıyorsa, bu değişkenin dışsal hareket ettiğini gösterir. Ayrıca, bağımsız değişkenlerden hangisinin zaman içinde bağıml değişkenlerdeki değişkenliği açıklamada "daha güçlü" olduğunu açıklama konusunda da bilgi vermektedir (Lütkepohl \& Kratzig, 2004: 180-185).

\section{AMPIRIKK BULGULAR}

\subsection{Durağanlık Analizi Sonuçları}

Birim kök testine başlamadan önce verilerin ölçeğini küçültmek ve normal bir dağılma sahip olmaları için logaritma dönüşümü yapılmıştır. Analizlere serilerin logaritmalı halleri ile devam edilmiş olup XRP serisi zaten oran olduğu için XRP serisinin logaritması alınmamıştır. Değişkenlerin doğrusal biçime getirilmesi için logaritmalarının alınmış halleri ' $\mathrm{L}$ ' notasyonu ile, farkı alınan seriler ise ' $\mathrm{DL}$ ' notasyonu ile gösterilmiştir. Serilerin durağan olup olmadıklarını görebilmek amaciyla ADF birim kök testi uygulanmıştır. BCH, ETH, LTC ve XRP olarak gösterilen değişkenler için yapılan ADF birim kök testlerinin sonuçları Tablo 1'de toplu bir şekilde verilmiştir.

Tablo.1. Serilerin Birim Kök Testi Sonuçları.

\begin{tabular}{|c|c|c|c|c|}
\hline \multicolumn{5}{|c|}{ Augmented Dickey-Fuller Testleri 03.08.2017 - 17.03.2020 } \\
\hline \multirow{2}{*}{ Değişkenler } & \multicolumn{3}{|c|}{ Düzey } & \multirow{2}{*}{ Karar } \\
\hline & t-istatistiği & $\mathrm{p}$ değeri & $\% 5$ kritik değer & \\
\hline $\mathrm{LBCH}$ & -1.908964 & 0.6241 & -3.574244 & Seri, düzeyde durağan değildir. \\
\hline LETH & -1.631547 & 0.7551 & -3.574244 & Seri, düzeyde durağan değildir. \\
\hline LLTC & -2.872946 & 0.1856 & -3.580623 & Seri, düzeyde durağan değildir. \\
\hline XRP & -3.595688 & 0.0492 & -3.587527 & Seri, düzeyde durağandır. \\
\hline \multirow{2}{*}{ Değişkenler } & & 1.Fark & & \multirow{2}{*}{ Karar } \\
\hline & t-istatistiği & $\mathrm{p}$ değeri & $\% 5$ kritik değer & \\
\hline DLBCH & -4.030624 & 0.0044 & -2.971853 & Seri, birinci farkta durağandır. \\
\hline DLETH & -3.091188 & 0.0388 & -2.971853 & Seri, birinci farkta durağandır. \\
\hline DLLTC & -3.671648 & 0.0104 & -2.971853 & Seri, birinci farkta durağandır. \\
\hline
\end{tabular}

Serilerin logaritmaları alınmış hallerine yapılan ADF testinin hipotezleri; vardir)

$H_{0}$ : Seri düzeyde durağan değildir (Birim kök

$H_{1}$ : Seri düzeyde durağandır.

şeklinde olup LBCH, LETH ve LLTC değişkeni serileri düzeyde durağan değildir. XRP serisi ise düzeyde durağandır. Düzeyde durağan olmayan değişkenler için 1. fark alınmış olup serilerin 1. farklarına ADF testi uygulanmıştır. Hipotezler, yukarıdaki hipotezle aynıdır. Birinci farkı alınan BCH, ETH ve LTC tabloda DLBCH, DLETH ve DLLTC ile belirtilmiş olup 1. farklar için hepsinde $H_{0}$ hipotezi reddedilmiş olup seriler 1. farkta durağan hale gelmiştir.

$$
\begin{aligned}
& \Delta \mathrm{LBCH} \sim \mathrm{I}(0) \rightarrow \mathrm{LBCH} \sim \mathrm{I}(1) \\
& \Delta \mathrm{LETH} \sim \mathrm{I}(0) \rightarrow \mathrm{LETH} \sim \mathrm{I}(1) \\
& \Delta \mathrm{LLTC} \sim \mathrm{I}(0) \rightarrow \mathrm{LLTC} \sim \mathrm{I}(1) \\
& \mathrm{XRP} \sim \mathrm{I}(0) \rightarrow \mathrm{XRP} \sim \mathrm{I}(0)
\end{aligned}
$$

\subsection{Granger Nedensellik Analizi Sonuçları}

Durağanlıktan sonraki aşama nedensellik ve VAR analizidir. Serilerin kaçıncı mertebede durağan olduklarını belirledik ve bundan sonraki analizlerde serilerin durağan halleri ile analize devam edilmiştir. Öncelikle ikişerli grup halinde serilerin tek yönlü ve iki yönlü nedensellik analizleri yapılacaktır. Bunun için
Granger nedensellik test denklemindeki gecikmeyi belirlemek için LogL, Olabilirlik oranı testi (LR), Son öngörü hatası (FPE), Akaike bilgi kriteri (AIC), Schwarz bilgi kriteri (SC) ve Hannan-Quinn (HQ) bilgi kriterlerinden yardım alınmıştır. Tablo.2'de Bitcoin Cash ve Ethereum arasındaki gecikme uzunluğuna ait bilgi kriterleri sonuçları verilmiştir. Cimrilik prensibi gereği 1 gecikme alınmıştır.

Bitcoin Cash ve Litecoin arasındaki gecikme uzunluğuna ait bilgi kriterleri sonuçları Tablo.3'te verilmiştir. Cimrilik prensibi gereği 1 gecikme alınmıştır.

Bitcoin Cash ve XRP arasındaki gecikme uzunluğuna ait bilgi kriterleri sonuçları Tablo.4'te verilmiştir. Cimrilik prensibi gereği 1 gecikme alınmıştır.

Ethereum ve Litecoin arasındaki gecikme uzunluğuna ait bilgi kriterleri sonuçları Tablo.5'te verilmiştir. Cimrilik prensibi gereği 1 gecikme alınmıştır.

Ethereum ve XRP arasındaki gecikme uzunluğuna ait bilgi kriterleri sonuçları Tablo.6'da verilmiştir. Cimrilik prensibi gereği 1 gecikme alınmıştır.

Litecoin ve XRP arasındaki gecikme uzunluğuna ait bilgi kriterleri sonuçları Tablo.7'de verilmiştir. Cimrilik prensibi gereği 3 gecikme alınmıştır. 
Tablo.2. VAR Gecikme Uzunluğu Belirleme Kriterleri (Bitcoin Cash-Ethereum)

\begin{tabular}{|l|l|l|l|l|l|l|}
\hline Gecikme & LogL & LR & FPE & AIC & SC & HQ \\
\hline 0 & -0.415997 & NA & 0.004100 & 0.178963 & 0.274951 & 0.207505 \\
\hline 1 & 6.580021 & $12.43736^{*}$ & $0.003290 *$ & $-0.042964 *$ & $0.244999^{*}$ & $0.042662^{*}$ \\
\hline 2 & 9.793675 & 5.237066 & 0.003511 & 0.015283 & 0.495223 & 0.157995 \\
\hline *Ait olduğu sütundaki bilgi kriterine ait en uggun gecikme uzunluğunu göstermektedir. \\
\hline
\end{tabular}

Tablo.3. VAR Gecikme Uzunluğu Belirleme Kriterleri (Bitcoin Cash-Litecoin)

\begin{tabular}{|l|l|l|l|l|l|l|}
\hline Gecikme & LogL & LR & FPE & AIC & SC & HQ \\
\hline 0 & 3.639122 & NA* & 0.002933 & -0.156107 & $-0.056629^{*}$ & -0.134518 \\
\hline 1 & 9.143509 & 9.436092 & $0.002551^{*}$ & -0.299382 & -0.000947 & $-0.234614 *$ \\
\hline 2 & 9.485596 & 0.521275 & 0.003668 & 0.048991 & 0.546383 & 0.156938 \\
\hline 3 & 11.23071 & 2.326815 & 0.004705 & 0.263742 & 0.960090 & 0.414868 \\
\hline 4 & 11.37929 & 0.169806 & 0.007249 & 0.630544 & 1.525849 & 0.824848 \\
\hline 5 & 13.47112 & 1.992223 & 0.009731 & 0.812274 & 1.906536 & 1.049757 \\
\hline 6 & 24.43883 & 8.356350 & 0.006040 & 0.148683 & 1.441901 & 0.429344 \\
\hline 7 & 26.56877 & 1.217110 & 0.009827 & 0.326784 & 1.818958 & 0.650624 \\
\hline 8 & 38.62401 & 4.592471 & 0.007815 & $-0.440382 *$ & 1.250750 & -0.073363 \\
\hline *Ait olduğu sütundaki bilgi kriterine ait en uygun gecikme uzunluğunu göstermektedir. & \\
\hline
\end{tabular}

Tablo.4. VAR Gecikme Uzunluğu Belirleme Kriterleri (Bitcoin Cash-XRP)

\begin{tabular}{|l|l|l|l|l|l|l|}
\hline Gecikme & LogL & LR & FPE & AIC & SC & HQ \\
\hline 0 & 14.47775 & NA & 0.001045 & -1.188357 & -1.088878 & -1.166767 \\
\hline 1 & 34.00151 & $33.46932 *$ & $0.000239^{*}$ & -2.666811 & $-2.368376^{*}$ & $-2.602043^{*}$ \\
\hline 2 & 34.98605 & 1.500253 & 0.000323 & -2.379624 & -1.882233 & -2.271678 \\
\hline 3 & 36.93244 & 2.595185 & 0.000407 & -2.184042 & -1.487694 & -2.032917 \\
\hline 4 & 40.84752 & 4.474378 & 0.000438 & -2.175955 & -1.280650 & -1.981651 \\
\hline 5 & 43.51697 & 2.542329 & 0.000556 & -2.049235 & -0.954974 & -1.811752 \\
\hline 6 & 45.45965 & 1.480140 & 0.000816 & -1.853300 & -0.560082 & -1.572639 \\
\hline 7 & 55.05563 & 5.483417 & 0.000652 & -2.386251 & -0.894076 & -2.062411 \\
\hline 8 & 62.56465 & 2.860576 & 0.000799 & $-2.720442 *$ & -1.029311 & -2.353424 \\
\hline *Ait olduğu sütundaki bilgi kriterine ait en uygun gecikme uzunluğunu göstermektedir. & \\
\hline
\end{tabular}

Tablo.5. VAR Gecikme Uzunluğu Belirleme Kriterleri (Ethereum-Litecoin)

\begin{tabular}{|l|l|l|l|l|l|l|}
\hline Gecikme & LogL & LR & FPE & AIC & SC & HQ \\
\hline 0 & 16.25176 & NA* & 0.001045 & -1.187646 & $-1.089475^{*}$ & -1.161601 \\
\hline 1 & 20.88258 & 8.103936 & $0.000994^{*}$ & $-1.240215^{*}$ & -0.945701 & $-1.162080^{*}$ \\
\hline 2 & 22.99643 & 3.346939 & 0.001175 & -1.083036 & -0.592180 & -0.952812 \\
\hline 3 & 23.28987 & 0.415698 & 0.001637 & -0.774156 & -0.086957 & -0.591842 \\
\hline 4 & 24.71331 & 1.779310 & 0.002116 & -0.559443 & 0.324097 & -0.325039 \\
\hline 5 & 26.29388 & 1.712282 & 0.002778 & -0.357824 & 0.722059 & -0.71330 \\
\hline$*$ Ait olduğu sütundaki bilgi kriterine ait engun gecikme uzunluğunu göstermektedir. \\
\hline \multicolumn{7}{|l}{} \\
\hline
\end{tabular}

Tablo.6. VAR Gecikme Uzunluğu Belirleme Kriterleri (Ethereum-XRP)

\begin{tabular}{|l|l|l|l|l|l|l|}
\hline Gecikme & LogL & LR & FPE & AIC & SC & HQ \\
\hline 0 & -127.4565 & NA & 72.42253 & 9.958196 & 10.05497 & 9.986064 \\
\hline 1 & -120.0942 & $13.02575^{*}$ & $56.02856^{*}$ & $9.699551^{*}$ & $9.989881^{*}$ & $9.783155^{*}$ \\
\hline 2 & -119.8517 & 0.391606 & 75.37984 & 9.988595 & 10.47248 & 10.12794 \\
\hline 3 & -119.6788 & 0.252756 & 102.9707 & 10.28298 & 10.96042 & 10.47806 \\
\hline *Ait olduğu sütundaki bilgi kriterine ait en uygun gecikme uzunluğunu göstermektedir. \\
\hline
\end{tabular}

Tablo.7. VAR Gecikme Uzunluğu Belirleme Kriterleri (Litecoin-XRP)

\begin{tabular}{|l|l|l|l|l|l|l|}
\hline Gecikme & LogL & LR & FPE & AIC & SC & HQ \\
\hline 0 & -25.06409 & NA & 0.032702 & 2.255340 & 2.353512 & 2.281385 \\
\hline 1 & 25.81627 & 89.04062 & 0.000659 & -1.651356 & -1.356842 & -1.573221 \\
\hline 2 & 26.04304 & 0.359065 & 0.000912 & -1.336920 & -0.846065 & -1.206696 \\
\hline 3 & 52.12977 & $36.95620^{*}$ & 0.000148 & -3.177481 & $-2.490283^{*}$ & -2.995167 \\
\hline 4 & 57.55996 & 6.787734 & 0.000137 & -3.296663 & -2.413123 & -3.062260 \\
\hline 5 & 63.28128 & 6.198095 & $0.000127 *$ & $-3.440107 *$ & -2.360224 & $-3.153613^{*}$ \\
\hline *Ait olduğu sütundaki bilgi kriterine ait en uygun gecikme uzunluğunu göstermektedir. \\
\hline \multicolumn{7}{|l}{} \\
\hline
\end{tabular}


Tablo.8. Granger Nedensellik Testi Sonuçları

\begin{tabular}{|l|c|c|c|c|}
\hline $\boldsymbol{H}_{\mathbf{0}}$ Hipotezleri & Gözlem & F-istatistiği & Olasıllk & Karar \\
\hline $\begin{array}{l}\text { DLETH serisi DLBCH serisinin Granger nedeni } \\
\text { değildir. }\end{array}$ & 28 & 0.06695 & 0.7980 & $H_{0}$ reddedilemez. \\
\hline $\begin{array}{l}\text { DLBCH serisi DLETH serisinin Granger nedeni } \\
\text { değildir. }\end{array}$ & 28 & 5.06188 & $0.0335^{*}$ & $H_{0}$ reddedilir. \\
\hline $\begin{array}{l}\text { DLLTC serisi DLBCH serisinin Granger nedeni } \\
\text { değildir. }\end{array}$ & 28 & 0.42309 & 0.5213 & $H_{0}$ reddedilemez. \\
\hline $\begin{array}{l}\text { DLBCH serisi DLLTC serisinin Granger nedeni } \\
\text { değildir. }\end{array}$ & 28 & 5.01812 & $0.0342^{*}$ & $H_{0}$ reddedilir. \\
\hline $\begin{array}{l}\text { XRP serisi DLBCH serisinin Granger nedeni } \\
\text { değildir. }\end{array}$ & 28 & 2.02831 & 0.1668 & $H_{0}$ reddedilemez. \\
\hline $\begin{array}{l}\text { DLBCH serisi XRP serisinin Granger nedeni } \\
\text { değildir. }\end{array}$ & 28 & 5.72225 & $0.0246^{*}$ & $H_{0}$ reddedilir. \\
\hline $\begin{array}{l}\text { DLLTC serisi DLETH serisinin Granger nedeni } \\
\text { değildir. }\end{array}$ & 28 & 8.81548 & $0.0065^{*}$ & $H_{0}$ reddedilir. \\
\hline $\begin{array}{l}\text { DLETH serisi DLLTC serisinin Granger nedeni } \\
\text { değildir. }\end{array}$ & 28 & 0.00023 & 0.9880 & $H_{0}$ reddedilemez. \\
\hline $\begin{array}{l}\text { XRP serisi DLETH serisinin Granger nedeni } \\
\text { değildir. }\end{array}$ & 28 & 4.18908 & 0.0513 & $H_{0}$ reddedilemez. \\
\hline $\begin{array}{l}\text { DLETH serisi XRP serisinin Granger nedeni } \\
\text { değildir. }\end{array}$ & 28 & 6.20269 & $0.0198^{*}$ & $H_{0}$ reddedilir. \\
\hline $\begin{array}{l}\text { XRP serisi DLLTC serisinin Granger nedeni } \\
\text { değildir. }\end{array}$ & 28 & 0.72562 & 0.5492 & $H_{0}$ reddedilemez. \\
\hline $\begin{array}{l}\text { DLLTC serisi XRP serisinin Granger nedeni } \\
\text { değildir. }\end{array}$ & 28 & 10.7495 & $0.0002^{*}$ & $H_{0}$ reddedilir. \\
\hline
\end{tabular}

Tablo.8'de ikili gruplar halinde seçilen değişkenlere uygulanan Granger nedensellik analizi testi sonuçları verilmiştir. Uygulanan testin sonucunda;

- BCH fiyatının, ETH fiyatının Granger nedeni olduğu

- BCH fiyatının, LTC fiyatının Granger nedeni olduğu

- BCH fiyatının, XRP fiyatının Granger nedeni olduğu

- $\quad$ LTC fiyatının, ETH fiyatının Granger nedeni olduğu

- ETH fiyatının, XRP fiyatının Granger nedeni olduğu

- LTC fiyatının, XRP fiyatının Granger nedeni olduğu

sonuçlarına ulaşılmıştır. Granger nedensellik analizi testi sonuçları ve yönleri Şekil.2'de görselleştirilmiştir.

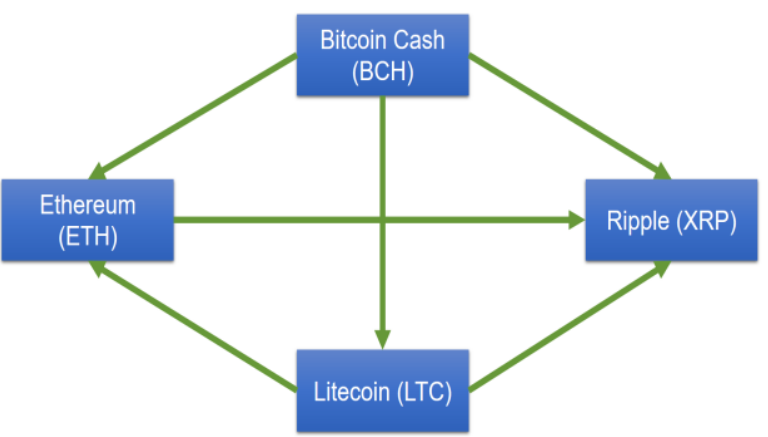

Şekil.2. Granger nedensellik analizi sonuçları görseli

\subsection{VAR Analizi Sonuçları}

Var analizi seriler arasında uzun dönemli ilişkilerini belirlemek için yapılmıştır. Öncelikle VAR test denklemi için gecikme derecesini belirlemek için bilgi kriterlerinden yararlanılmıştır. Tablo.9'da bilgi kriterleri sonuçları verilmiş olup cimrilik prensibi gereği 1 gecikme alınmıştır. Fakat sabit varyans varsayımını sağlamadığı için 2 gecikme alınmıştır. Varsayımlar 2 gecikmede sağlanmıştır. Değişkenlere ait VAR modeli ise Tablo.10'da verilmiştir.

\subsection{Otokorelasyon (LM) ve White Değişen Varyans Testleri}

Elde edilen VAR modelinde yapısal anlamda bir sorun olup olmadığının tespitine yönelik ayrıca Otokorelasyon (LM) ve White Değişen Varyans testleri yapılmıştır.

Otokorelasyon testine ilişkin sonuçlar Tablo.11'de gösterilmektedir.

Tahmin edilen VAR modelindeki hata terimlerinin birbiri ile ilişkili olup olmadıklarını belirlemek amacıyla yapılan bu test, 12 gecikme düzeyinde de otokorelasyon olmadığını göstermektedir. Hata terimlerinin varyansının bütün örneklem için sabit olup olmadığının belirlenmesi amacıyla yapılan White Değişen Varyans Testi sonuçları ise Tablo.12'de gösterilmektedir.

Ki-kare değeri tahmin edilen modelde değişen varyans problemi olmadığını başka bir ifadeyle sabit varyans varsayımının geçerli olduğunu göstermektedir. 
Tablo.9. DLBCH, DLETH, DLLTC, XRP içsel değişkenleri için değişken gecikme sırası seçim kriterleri

\begin{tabular}{|l|l|l|l|l|l|l|}
\hline Gecikme & LogL & LR & FPE & AIC & SC & HQ \\
\hline 0 & -119.8704 & NA & 0.113519 & 9.175588 & $9.367564^{*}$ & 9.232672 \\
\hline 1 & -95.18565 & $40.22706^{*}$ & 0.060692 & 8.532270 & 9.492149 & $8.817693^{*}$ \\
\hline 2 & -77.17438 & 24.01503 & $0.057137^{*}$ & $8.383287^{*}$ & 10.11107 & 8.897048 \\
\hline
\end{tabular}

Tablo.10. VAR Modeli

\begin{tabular}{|l|l|l|l|l|}
\hline & DLOGBCH & DLOGETH & DLOGLTC & XRP \\
\hline \multirow{3}{*}{ DLOGBCH(-1) } & 0.259523 & 0.254390 & 0.444469 & 15.11548 \\
& $(0.27800)$ & $(0.19602)$ & $(0.25035)$ & $(13.3825)$ \\
& {$[0.93352]$} & {$[1.29778]$} & {$[1.77537]$} & {$[1.12950]$} \\
\hline \multirow{3}{*}{ DLOGBCH(-2) } & -0.226748 & 0.054608 & -0.455499 & 44.28807 \\
& $(0.029383)$ & $(0.20718)$ & $(0.26461)$ & $(14.1443)$ \\
& {$[-0.77170]$} & {$[0.26358]$} & {$[-1.72143]$} & {$[3.13116]$} \\
\hline \multirow{5}{*}{ DLOGETH(-1) } & -0.420891 & -0.383857 & -0.425261 & -65.38790 \\
& $(0.59716)$ & $(0.42105)$ & $(0.53776)$ & $(28.7458)$ \\
& {$[-0.70482]$} & {$[-0.91166]$} & {$[-0.79080]$} & {$[-2.27469]$} \\
\hline \multirow{3}{*}{ DLOGLTC(-1) } & -0.259922 & -0.128793 & 0.470125 & 4.900467 \\
& $(0.59105)$ & $(0.41675)$ & $(0.53226)$ & $(28.4519)$ \\
& {$[-0.43976]$} & {$[-0.30904]$} & {$[0.88325]$} & {$[0.17224]$} \\
\hline \multirow{3}{*}{ DLOGLTC(-2) } & 0.442657 & 0.486672 & 0.317380 & 90.11164 \\
& $(0.38852)$ & $(0.27394)$ & $(0.34988)$ & $(18.7025)$ \\
\hline \multirow{3}{*}{ XRP(-1) } & {$[1.13934]$} & {$[1.77654]$} & {$[0.90712]$} & {$[4.81817]$} \\
\hline & 0.679520 & 0.130582 & 0.131931 & -80.08817 \\
& $(0.51680)$ & $(0.36440)$ & $(0.46540)$ & $(24.8777)$ \\
& {$[1.31485]$} & {$[0.35835]$} & {$[0.28348]$} & {$[-3.21928]$} \\
\hline & -0.004642 & -0.000323 & $-4.10 \mathrm{E}-05$ & 0.881644 \\
& $(0.00394)$ & $(0.00278)$ & $(0.00355)$ & $(0.18968)$ \\
& {$[-1.17806]$} & {$[-0.11621]$} & {$[-0.01155]$} & {$[4.64817]$} \\
\hline & 0.001377 & -0.000760 & -0.001296 & -0.185437 \\
& $(0.00321)$ & $(0.00226)$ & $(0.00289)$ & $(0.15439)$ \\
& {$[0.42932]$} & {$[-0.33609]$} & {$[-0.44878]$} & {$[-1.20108]$} \\
\hline & -0.019114 & -0.011106 & 0.007578 & 2.205497 \\
& $(0.07934)$ & $(0.05594)$ & $(0.07145)$ & $(3.81930)$ \\
& {$[-0.24091]$} & {$[-0.19853]$} & {$[0.10606]$} & {$[0.57746]$} \\
\hline
\end{tabular}

Tablo.11. Otokorelasyon-LM Testi Sonuçları

\begin{tabular}{|l|l|l|}
\hline Gecikme & LM-İstatistiği & Olasılık \\
\hline 1 & 28.85866 & 0.0249 \\
\hline 2 & 24.97080 & 0.0703 \\
\hline 3 & 16.72149 & 0.4038 \\
\hline 4 & 10.67226 & 0.8292 \\
\hline 5 & 15.24619 & 0.5067 \\
\hline 6 & 8.532505 & 0.9314 \\
\hline 7 & 25.88068 & 0.0557 \\
\hline 8 & 14.89543 & 0.5323 \\
\hline 9 & 11.29871 & 0.7907 \\
\hline 10 & 7.964712 & 0.9499 \\
\hline 11 & 14.18828 & 0.5847 \\
\hline 12 & 8.866400 & 0.9188 \\
\hline
\end{tabular}

Tablo.12. White Değişen Varyans Testi Sonuçları

\begin{tabular}{|l|l|l|}
\hline Ki-Kare & df & Olasılık \\
\hline 165.8825 & 160 & 0.3587 \\
\hline
\end{tabular}




\subsection{Kararlılık Analizi}

VAR modelinin geçerliliği için, ilk olarak modelin kararlılığının ortaya konması gerekmektedir. Bu amaçla VAR modeli AR karakteristik polinomiyalinin kökleri hesaplanmıştır. Eğer katsayı matrisinin öz değerlerinin hepsi birim çemberin içerisinde ise sistem durağan, özdeğerlerinin en az bir tanesi birim çemberin üzerinde veya dışarısında ise sistem durağan değildir veya giderek genişleyen bir özellik gösterir. Birim daire dışına çıkan herhangi bir kökün olmadığı Şekil.3'de görülmektedir. $\mathrm{Bu}$ da VAR modelinde kararlılığın sağlandığını ortaya koymaktadır.

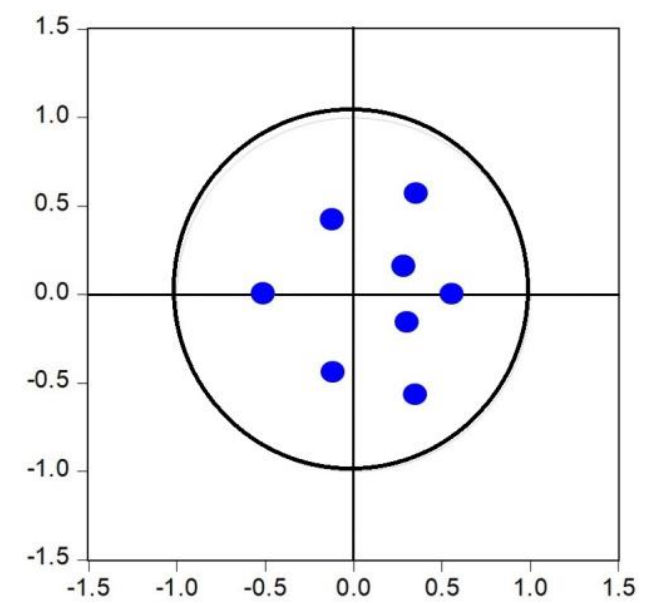

Şekil.3. AR Karakteristik Polinomiyalinin Kökleri

\subsection{Etki-Tepki Fonksiyonu ve Grafikleri}

VAR denklem sistemi uygulandiktan sonra VAR sistemi içerisinde yer alan Etki-Tepki Analizi ve Varyans Ayrıştırması Analizi yapılmıştır. VAR modelinin kararlılık koşulunu sağlaması etki-tepki katsayılarının elde edilebileceğini ortaya koymaktadır. Modelin geçerliliğinin saptanması sonrasında bir değişkende meydana gelen şoklar karşısında diğer değişkenlerin gelecekte nasıl tepki verdiğini sayılarla ifade etmek açısından etki-tepki fonksiyonları elde edilmiş ve grafikleri Şekil.4'de verilmiştir. Tablo.13'de ise herhangi bir seride meydana gelen şoka diğer serilerin 10 dönem boyunca verdiği tepkiler tablolaştırılmıştır.

Etki-Tepki fonksiyonlarında dikey eksende ilgili değişkene verilen bir standart sapma şokun diğer değişkene olan etkisinin yönü ve büyüklüğü, yatay eksende ise dönem (periyot) yer almaktadır. Grafiklerdeki mavi çizgiler şok karşısında ilgili değişkenin vereceği tepkiyi gösterirken, kırmızı renkle ifade edilen çizgiler ise 2 standart sapma güven aralıklarını ifade etmektedir.

Şekil.4'de yer alan grafikler, modelde analizde yer verilen değişkenlerde meydana gelen şoklara karşı birinci surada Bitcoin Cash'in; ikinci sırada Ethereum'un; üçüncü sırada Litecoin'in ve dördüncü sırada XRP'nin tepkisini göstermektedir.
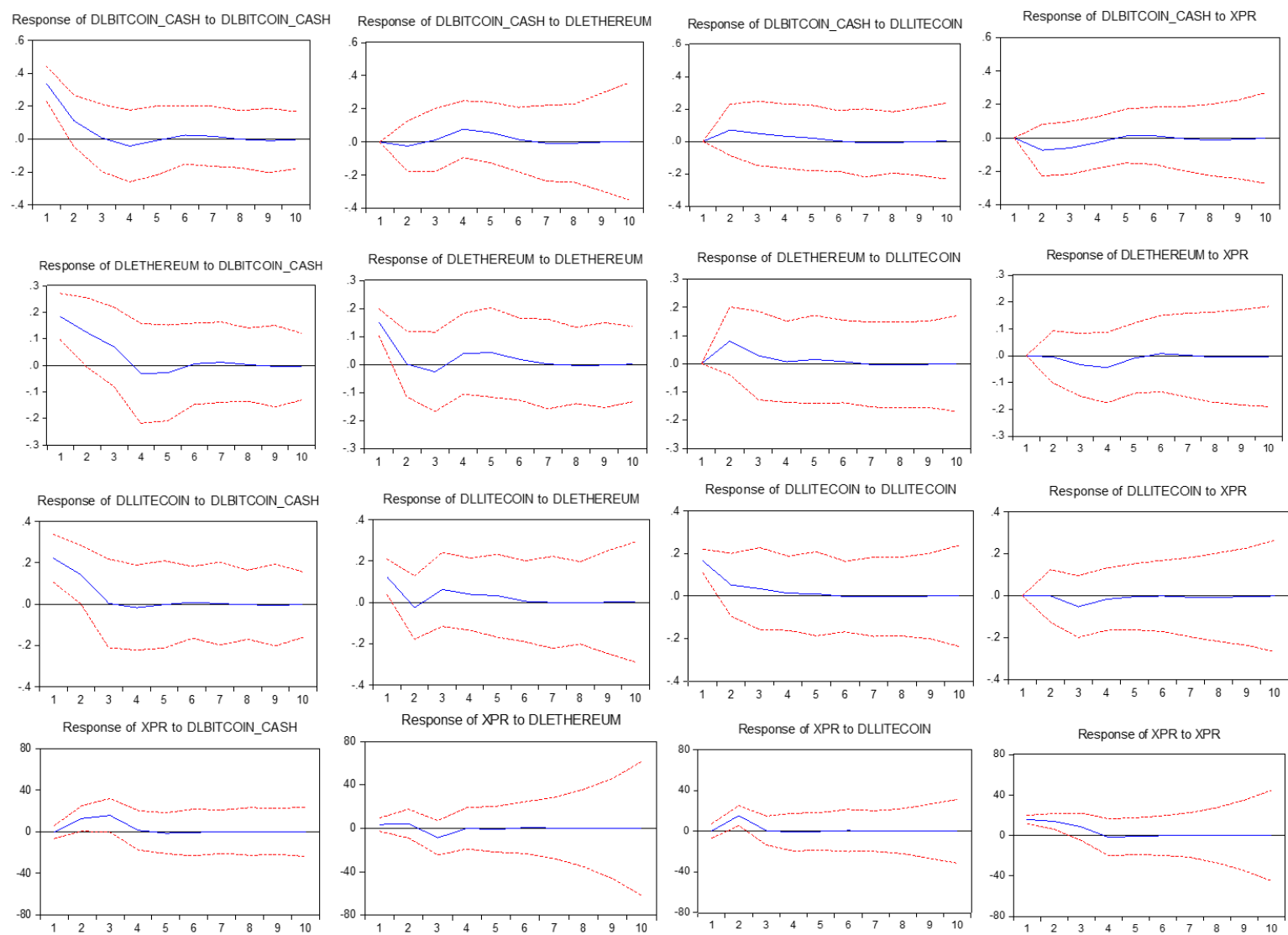

Şekil.4. Etki-Tepki Fonksiyonları Grafikleri 
Tablo.13. Herhangi bir seride meydana gelen şoka diğer serilerin dönem bazındaki tepkileri

\begin{tabular}{|c|c|c|c|c|c|c|c|c|}
\hline & \multicolumn{4}{|c|}{ Herhangi bir serideki 干1 birimlik şoka BCH serisinin dönem bazındaki tepkisi } & \multicolumn{4}{|c|}{ Herhangi bir serideki 干1 birimlik şoka ETH serisinin dönem bazındaki tepkisi } \\
\hline & DLBCH & DLETH & DLLTC & XRP & DLBCH & DLETH & DLLTC & XRP \\
\hline 1 & $\begin{array}{l}0.337649 \\
(0.04595) \\
\end{array}$ & $\begin{array}{l}0.000000 \\
(0.00000) \\
\end{array}$ & $\begin{array}{l}0.000000 \\
(0.00000) \\
\end{array}$ & $\begin{array}{l}0.000000 \\
(0.00000) \\
\end{array}$ & $\begin{array}{l}0.183927 \\
(0.03838) \\
\end{array}$ & $\begin{array}{l}0.151164 \\
(0.02057) \\
\end{array}$ & $\begin{array}{l}0.000000 \\
(0.00000) \\
\end{array}$ & $\begin{array}{l}0.000000 \\
(0.00000) \\
\end{array}$ \\
\hline 2 & $\begin{array}{l}0.110326 \\
(0.06909) \\
\end{array}$ & $\begin{array}{l}-0.025062 \\
(0.07493) \\
\end{array}$ & $\begin{array}{l}0.071445 \\
(0.06728) \\
\end{array}$ & $\begin{array}{l}-0.073630 \\
(0.06330) \\
\end{array}$ & $\begin{array}{l}0.123725 \\
(0.05081) \\
\end{array}$ & $\begin{array}{l}0.001108 \\
(0.05323)\end{array}$ & $\begin{array}{l}0.080681 \\
(0.04717) \\
\end{array}$ & $\begin{array}{l}-0.005121 \\
(0.04407)\end{array}$ \\
\hline 3 & $\begin{array}{l}0.006481 \\
(0.06751) \\
\end{array}$ & $\begin{array}{l}0.011339 \\
(0.07500)\end{array}$ & $\begin{array}{l}0.050081 \\
(0.07045) \\
\end{array}$ & $\begin{array}{l}-0.060315 \\
(0.06489) \\
\end{array}$ & $\begin{array}{l}0.069861 \\
(0.05211) \\
\end{array}$ & $\begin{array}{l}-0.026397 \\
(0.05694) \\
\end{array}$ & $\begin{array}{l}0.029237 \\
(0.05352) \\
\end{array}$ & $\begin{array}{l}-0.033652 \\
(0.05052) \\
\end{array}$ \\
\hline 4 & $\begin{array}{l}-0.042255 \\
(0.05853) \\
\end{array}$ & $\begin{array}{l}0.076678 \\
(0.05393) \\
\end{array}$ & $\begin{array}{l}0.032614 \\
(0.05651) \\
\end{array}$ & $\begin{array}{l}-0.027312 \\
(0.05783) \\
\end{array}$ & $\begin{array}{l}-0.029578 \\
(0.04764) \\
\end{array}$ & $\begin{array}{l}0.038428 \\
(0.04546) \\
\end{array}$ & $\begin{array}{l}0.006976 \\
(0.04619) \\
\end{array}$ & $\begin{array}{l}-0.044515 \\
(0.04947) \\
\end{array}$ \\
\hline 5 & $\begin{array}{l}-0.008093 \\
(0.05074)\end{array}$ & $\begin{array}{l}0.056385 \\
(0.04827) \\
\end{array}$ & $\begin{array}{l}0.021286 \\
(0.04111) \\
\end{array}$ & $\begin{array}{l}0.011103 \\
(0.04913)\end{array}$ & $\begin{array}{l}-0.027993 \\
(0.04163) \\
\end{array}$ & $\begin{array}{l}0.042900 \\
(0.03815) \\
\end{array}$ & $\begin{array}{l}0.015361 \\
(0.03462) \\
\end{array}$ & $\begin{array}{l}-0.009535 \\
(0.04071) \\
\end{array}$ \\
\hline 6 & $\begin{array}{l}0.023947 \\
(0.03710) \\
\end{array}$ & $\begin{array}{l}0.014348 \\
(0.03802) \\
\end{array}$ & $\begin{array}{l}0.002800 \\
(0.02974) \\
\end{array}$ & $\begin{array}{l}0.012517 \\
(0.03628) \\
\end{array}$ & $\begin{array}{l}0.006620 \\
(0.02819) \\
\end{array}$ & $\begin{array}{l}0.018283 \\
(0.03088) \\
\end{array}$ & $\begin{array}{l}0.007916 \\
(0.02545) \\
\end{array}$ & $\begin{array}{l}0.007842 \\
(0.02948) \\
\end{array}$ \\
\hline 7 & $\begin{array}{l}0.016745 \\
(0.03012)\end{array}$ & $\begin{array}{l}-0.007599 \\
(0.03035)\end{array}$ & $\begin{array}{l}-0.008986 \\
(0.02135)\end{array}$ & $\begin{array}{l}-0.004330 \\
(0.02626)\end{array}$ & $\begin{array}{l}0.012258 \\
(0.02260)\end{array}$ & $\begin{array}{l}0.001499 \\
(0.02453)\end{array}$ & $\begin{array}{l}-0.003113 \\
(0.01534)\end{array}$ & $\begin{array}{l}0.001524 \\
(0.01950)\end{array}$ \\
\hline 8 & $\begin{array}{l}-0.001597 \\
(0.02134)\end{array}$ & $\begin{array}{l}-0.007555 \\
(0.02378)\end{array}$ & $\begin{array}{l}-0.006801 \\
(0.01497)\end{array}$ & $\begin{array}{l}-0.012829 \\
(0.01961)\end{array}$ & $\begin{array}{l}0.003139 \\
(0.01696)\end{array}$ & $\begin{array}{l}-0.003885 \\
(0.01864)\end{array}$ & $\begin{array}{l}-0.004765 \\
(0.01065)\end{array}$ & $\begin{array}{l}-0.005781 \\
(0.01384)\end{array}$ \\
\hline 9 & $\begin{array}{l}-0.008911 \\
(0.01641) \\
\end{array}$ & $\begin{array}{l}-0.000582 \\
(0.01567) \\
\end{array}$ & $\begin{array}{l}-0.000901 \\
(0.00953) \\
\end{array}$ & $\begin{array}{l}-0.008990 \\
(0.01327) \\
\end{array}$ & $\begin{array}{l}-0.003233 \\
(0.01166) \\
\end{array}$ & $\begin{array}{l}-0.002351 \\
(0.01216) \\
\end{array}$ & $\begin{array}{l}-0.001968 \\
(0.00633) \\
\end{array}$ & $\begin{array}{l}-0.006271 \\
(0.00998) \\
\end{array}$ \\
\hline 10 & $\begin{array}{l}-0.006195 \\
(0.01224)\end{array}$ & $\begin{array}{l}0.004132 \\
(0.01184)\end{array}$ & $\begin{array}{l}0.002115 \\
(0.00646)\end{array}$ & $\begin{array}{l}-0.002090 \\
(0.00901)\end{array}$ & $\begin{array}{l}-0.004265 \\
(0.00890)\end{array}$ & $\begin{array}{l}0.001110 \\
(0.00801)\end{array}$ & $\begin{array}{l}0.000409 \\
(0.00391)\end{array}$ & $\begin{array}{l}-0.003120 \\
(0.00691)\end{array}$ \\
\hline & Herhangi $\mathrm{b}$ & i $\mp 1$ birimlil & nem bazında & & Herhangi b & birimlik şoka & dönem bazı & \\
\hline & DLBCH & DLETH & DLLTC & XRP & DLBCH & DLETH & DLLTC & XRP \\
\hline 1 & $\begin{array}{l}0.222577 \\
(0.05007) \\
\end{array}$ & $\begin{array}{l}0.123829 \\
(0.03613) \\
\end{array}$ & $\begin{array}{l}0.166076 \\
(0.02260) \\
\end{array}$ & $\begin{array}{l}0.000000 \\
(0.00000)\end{array}$ & $\begin{array}{l}-0.341620 \\
(3.12766) \\
\end{array}$ & $\begin{array}{l}3.501094 \\
(3.09081) \\
\end{array}$ & \begin{tabular}{|l|l}
0.445975 \\
$(3.05327)$ \\
\end{tabular} & $\begin{array}{l}15.86212 \\
(2.15856) \\
\end{array}$ \\
\hline 2 & $\begin{array}{l}0.142513 \\
(0.06210) \\
\end{array}$ & $\begin{array}{l}-0.025127 \\
(0.06590) \\
\end{array}$ & $\begin{array}{l}0.052691 \\
(0.05902) \\
\end{array}$ & $\begin{array}{l}-0.000650 \\
(0.05628) \\
\end{array}$ & $\begin{array}{l}12.83275 \\
(5.41449) \\
\end{array}$ & $\begin{array}{l}4.360841 \\
(5.33033) \\
\end{array}$ & $\begin{array}{l}15.35858 \\
(4.62795) \\
\end{array}$ & $\begin{array}{l}13.98474 \\
(3.56002) \\
\end{array}$ \\
\hline 3 & $\begin{array}{l}0.003603 \\
(0.06308) \\
\end{array}$ & $\begin{array}{l}0.063101 \\
(0.06944) \\
\end{array}$ & $\begin{array}{l}0.034871 \\
(0.06525) \\
\end{array}$ & $\begin{array}{l}-0.051888 \\
(0.06139) \\
\end{array}$ & $\begin{array}{l}15.82615 \\
(6.37669) \\
\end{array}$ & $\begin{array}{l}-8.696492 \\
(6.51707) \\
\end{array}$ & $\begin{array}{l}0.709818 \\
(6.02494) \\
\end{array}$ & $\begin{array}{l}8.551503 \\
(5.86097) \\
\end{array}$ \\
\hline 4 & $\begin{array}{l}-0.016253 \\
(0.05484) \\
\end{array}$ & $\begin{array}{l}0.039618 \\
(0.05078) \\
\end{array}$ & $\begin{array}{l}0.013295 \\
(0.05150) \\
\end{array}$ & $\begin{array}{l}-0.016398 \\
(0.05539) \\
\end{array}$ & $\begin{array}{l}1.506774 \\
(6.45470) \\
\end{array}$ & $\begin{array}{l}0.015578 \\
(6.80921) \\
\end{array}$ & $\begin{array}{l}-0.895124 \\
(6.47935) \\
\end{array}$ & $\begin{array}{l}-1.674870 \\
(6.71472) \\
\end{array}$ \\
\hline 5 & $\begin{array}{l}-0.001570 \\
(0.04394)\end{array}$ & $\begin{array}{l}0.032335 \\
(0.04068)\end{array}$ & $\begin{array}{l}0.010399 \\
(0.03656)\end{array}$ & $\begin{array}{l}-0.004622 \\
(0.04494)\end{array}$ & $\begin{array}{l}-1.434695 \\
(5.56025)\end{array}$ & $\begin{array}{l}-0.838110 \\
(5.27912) \\
\end{array}$ & $\begin{array}{l}-0.117451 \\
(5.28923) \\
\end{array}$ & $\begin{array}{l}-0.722657 \\
(5.53522)\end{array}$ \\
\hline 6 & $\begin{array}{l}0.009112 \\
(0.02728) \\
\end{array}$ & $\begin{array}{l}0.005460 \\
(0.03134) \\
\end{array}$ & $\begin{array}{l}-0.002428 \\
(0.02079) \\
\end{array}$ & $\begin{array}{l}-0.000927 \\
(0.03140) \\
\end{array}$ & $\begin{array}{l}-0.692348 \\
(3.90165) \\
\end{array}$ & $\begin{array}{l}0.630476 \\
(3.69519) \\
\end{array}$ & $\begin{array}{l}0.730689 \\
(3.44707) \\
\end{array}$ & $\begin{array}{l}-0.066200 \\
(3.93915) \\
\end{array}$ \\
\hline 7 & $\begin{array}{l}0.002927 \\
(0.02206)\end{array}$ & $\begin{array}{l}0.000147 \\
(0.02499)\end{array}$ & $\begin{array}{l}-0.003872 \\
(0.01334)\end{array}$ & $\begin{array}{l}-0.007276 \\
(0.02039)\end{array}$ & $\begin{array}{l}0.035944 \\
(2.68920) \\
\end{array}$ & $\begin{array}{l}0.342370 \\
(2.91276)\end{array}$ & $\begin{array}{l}0.156996 \\
(1.50701)\end{array}$ & $\begin{array}{l}0.483736 \\
(2.44748)\end{array}$ \\
\hline 8 & $\begin{array}{l}-0.002538 \\
(0.01323)\end{array}$ & $\begin{array}{l}-0.002019 \\
(0.01633) \\
\end{array}$ & $\begin{array}{l}-0.002727 \\
(0.00882)\end{array}$ & $\begin{array}{l}-0.006953 \\
(0.01204) \\
\end{array}$ & $\begin{array}{l}0.238666 \\
(1.85969)\end{array}$ & $\begin{array}{l}0.273097 \\
(2.21877) \\
\end{array}$ & $\begin{array}{l}0.078992 \\
(0.84946)\end{array}$ & $\begin{array}{l}0.285032 \\
(1.35970)\end{array}$ \\
\hline 9 & $\begin{array}{l}-0.004385 \\
(0.00924) \\
\end{array}$ & $\begin{array}{l}0.001384 \\
(0.00901) \\
\end{array}$ & $\begin{array}{l}5.03 \mathrm{E}-05 \\
(0.00442) \\
\end{array}$ & $\begin{array}{l}-0.004360 \\
(0.00840) \\
\end{array}$ & $\begin{array}{l}0.312885 \\
(1.22694) \\
\end{array}$ & $\begin{array}{l}-0.205791 \\
(1.42078) \\
\end{array}$ & $\begin{array}{c}-0.099549 \\
(0.61560) \\
\end{array}$ & $\begin{array}{l}0.117499 \\
(0.92584)\end{array}$ \\
\hline 10 & $\begin{array}{l}-0.002432 \\
(0.00663) \\
\end{array}$ & $\begin{array}{l}0.002183 \\
(0.00617) \\
\end{array}$ & $\begin{array}{l}0.000852 \\
(0.00284) \\
\end{array}$ & $\begin{array}{l}-0.000878 \\
(0.00532) \\
\end{array}$ & $\begin{array}{l}0.061119 \\
(0.90545) \\
\end{array}$ & $\begin{array}{l}-0.154394 \\
(0.71750) \\
\end{array}$ & $\begin{array}{l}-0.088957 \\
(0.42632) \\
\end{array}$ & $\begin{array}{l}-0.107611 \\
(0.76052) \\
\end{array}$ \\
\hline
\end{tabular}


Değişkenlerde meydana gelen şoklara karşı tepkiler şöyle özetlenebilir:

Ethereum serisinde \pm 1 standart sapmalık şok karşısında Bitcoin Cash serisi 1. Dönemde tepkisiz kalırken, 2.,7.,8 ve 9. dönemlerde negatif yönde tepki vermiştir. Diğer tüm dönemlerde ise pozitif yönlü tepki vermiştir. Son dönemde ise eski dönem dengesinin üstünde seyretmiştir. Litecoin serisinde \pm 1 standart sapmalık şok karşısında Bitcoin Cash serisi 1. dönemde tepkisiz kalmıştır. 7.,8. ve 9. dönemlerde negatif yönlü tepki vermiştir ve diğer tüm dönemlerde pozitif yönlü tepki vermiştir. Negatif yönlü maksimum tepkisini 2. dönemde vermiştir. Son dönemde ise eski dönem dengesinin üstünde seyretmiştir. XRP serisinde \pm 1 standart sapmalık şok karşısında Bitcoin Cash serisi 1. dönem herhangi bir tepki vermemiştir. 5. ve 6. dönemde pozitif yönlü tepki vermiştir; diğer dönemlerde ise negatif yönlü tepki vermiştir. Negatif yönlü maksimum tepkisini ikinci dönemde vermiştir. Son dönemde de eski dönem dengesinin altında seyretmiştir.

Bitcoin Cash serisinde meydana gelen \pm 1 standart sapmalık şok karşısında Ethereum serisi 1.,2.,3.,6.,7. ve 8 . dönemlerde pozitif yönde tepki vermiştir. Diğer tüm dönemlerde negatif yönlü tepki vermiştir. Son döneme gelindiğinde ise eski dönem dengesinin altında bir seyir izlemiştir. Litecoin serisinde \pm 1 standart sapmalık şok karşısında Ethereum serisi 1. dönem herhangi bir tepki vermemiştir. 2. dönemde ise pozitif yönlü güçlü bir tepki görülürken sonraki dönemlerde pozitif yönlü etki azalarak 6. dönemin sonuna kadar devam etmiştir. 7.,8. ve 9 . dönemlerde ise negatif yönlü tepki vermiştir. Son dönemde ise eski dönem seviyesinin üzerinde bir seyir izlemiştir. XRP serisindeki \pm 1 birimlik şok karşısında Ethereum serisi 1. dönemde tepki göstermemiştir. 6. ve 7. dönemlerde pozitif yönlü bir tepki görülürken diğer tüm dönemlerde negatif yönlü tepki göstermiştir.

Bitcoin Cash serisinde \pm 1 standart sapmalık şok karşısında Litecoin serisi 1. dönemde pozitif yönlü güçlü bir tepki vermekte ve sonrasında bu pozitif etki ilerleyen dönemlerde azalarak 3. dönemle birlikte eski fiyat seviyesine geri dönmektedir. Ethereum serisinde \pm 1 standart sapmalık şok karşısında Litecoin serisi sadece 2. ve 8 . dönemlerde negatif tepki verirken diğer tüm dönemlerde pozitif tepki vermiştir. 6. dönemden son döneme kadar olan bu pozitif tepki eski fiyat seviyesine çok yakın bir şekilde seyretmektedir. XRP serisinde \pm 1 standart sapmalık şok karşısında ise Litecoin serisi çok küçük bir tepki vermekte, eski seviyesi dolaylarında kalmaya devam etmektedir.

Bitcoin Cash serisinde \pm 1 standart sapmalık şok karşısında XRP serisi 2. dönemden itibaren artış şeklinde tepki vermekte, tepki 3. dönemde maksimuma ulaşmakta ve ardından azalarak eski seviyesine geri dönmektedir. Ethereum serisinde \pm 1 standart sapmalık şok karşısında XRP serisi 1. ve 2. dönemlerde pozitif tepki, 3. dönemde ise negatif tepki vermektedir. Ardından eski seviyesi dolaylarında kalmaya devam etmektedir. Litecoin serisinde meydana gelen \pm 1 standart sapmalık şok karşısında XRP serisi 2. dönemde pozitif yönde en büyük tepkiyi verdikten sonra eski seviyesi dolaylarında seyretmektedir.

\section{7. Çoklu Varyans Ayrıştırma Sonuçları}

Etki-Tepki fonksiyonunda bir değişkenin hatasına \pm 1 standart sapmalık şok verilmesi durumunda, bu şokun sonraki dönemlerde diğer değişkenleri de etkilediği gösterilmiştir. Şimdi ise Varyans Ayrıştırma Analizi bir değişkenin kendi şoklarından kaynaklanan hareketler ile diğer değişkenlerin şoklarından kaynaklanan değişimlerin birbirine oranını göstermektedir.

Eğer birinci değişkenin hata varyansı, diğer ikinci değişkenin hata varyansına oranı tüm dönemlerde sıfır ise, ikinci değişkenin dişsal (ekzojen) değişken olduğu sonucuna ulaşılır. Tersine hata varyanslarının oranı sıfırdan farklı ise o zaman da ikinci değişkenin içsel olduğu anlamına gelir (Sevüktekin \& Çınar, 2017: 515).

Etki-Tepki fonksiyonlarının grafiklerinin yorumlanmasından sonra sırada sistemde bulunan tüm değişkenlerin kendisi ve diğer değişkenler üzerindeki etkilerini görebilmek için on dönemlik varyans ayrıştırma sonuçları Tablo 14'de verilmektedir.

Varyans ayrıştırması sonuçlarına göre; Bitcoin Cash'in hata varyansında meydana gelen değişimin ilk dönem tamamı kendisi tarafından açıklanmaktadır. İkinci dönemde değişimin \%91,87'si kendisinden, \%0,45'i Ethereum'dan, \%3,71'i Litecoin'den ve \%3,94'ü Ripple tarafından açıklanmaktadır. Son dönemde ise standart sapmadaki değişimin \%81,25'i kendisi tarafından açıklanmaya devam ederken; \%6,39'u Ethereum, \%5,83'ü Litecoin ve \%6,51'i Ripple tarafindan açıklanmaktadır. Ethereum'un hata varyansının ilk dönemde \%59,68'i Bitcoin Cash tarafindan, \%40,31'i kendisi tarafindan açıklanmaktadır. Sonraki dönemlerde kendisi tarafından açıklanma yüzdesi düşerken, Bitcoin Cash tarafından açıklanma yüzdesi 2 . ve 3 . dönemlerde arttıktan sonra 4 . dönemde bir düşüş sonrası 5 . dönemle birlikte yatay bir seyir izlemeye başlamıştır.

1. dönemde Ethereum'un hata varyansını açıklamada Litecoin'in etkisi yokken 2 . dönemde $\% 8$ 'e yükselmiş ve daha sonra son döneme kadar o da \%8 civarında yatay bir seyir izlemiştir. Ethereum'un hata varyansını açıklamada Ripple'ın ise diğerlerine oranla daha sınırlı bir düzeyde kaldığı görülmektedir. Litecoin açısından bakıldığında, varyans ayrıştırma sonuçları yüksek oranda Bitcoin Cash'in etkisine ve Bitcoin Cash'e nispeten az olmakla birlikte yine kendisine göre yüksek oranda Ethereum'un etkisini gözler önüne sermektedir. Çünkü 10. dönem itibariyle Litecoin'in hata varyansının \%24,94'ü kendi, \%17,67'si Ethereum ve \%54,95'i Bitcoin Cash tarafindan açıklanmaktadır. Ripple'ın hata varyansının ise yine büyük bir bölümünün Bitcoin Cash tarafından açıklandığı görülmektedir. Son dönemde Ripple hata varyansının \%32,56's1 Bitcoin Cash, \%8,38'i Ethereum, \%18,44'ü Litecoin ve \%40,60’ı kendisi tarafından açıklanmaktadır. Ayrıca, varyans ayrıştırmasının sonuçlarının grafiksel gösterimleri Şekil.5'te verilmiştir. 
Tablo.14. Değişkenlere Ait Varyans Ayrıştırma Sonuçları

\begin{tabular}{|l|l|l|l|l|l|l|l|l|}
\hline & DLBCH & \multicolumn{5}{l|}{ DLETH } \\
\hline & DLBCH & DLETH & DLLTC & XRP & DLBCH & DLETH & DLLTC & XRP \\
\hline 1 & 100.0000 & 0.000000 & 0.000000 & 0.000000 & 59.68472 & 40.31528 & 0.000000 & 0.000000 \\
\hline 2 & 91.87822 & 0.457348 & 3.716771 & 3.947663 & 62.57549 & 29.10151 & 8.289596 & 0.033401 \\
\hline 3 & 87.86735 & 0.526735 & 5.299324 & 6.306587 & 62.74616 & 27.35377 & 8.554117 & 1.345949 \\
\hline 4 & 83.59651 & 4.333896 & 5.666091 & 6.403501 & 60.67420 & 27.66115 & 8.193609 & 3.471034 \\
\hline 5 & 81.60295 & 6.254075 & 5.816831 & 6.326145 & 59.59649 & 28.75741 & 8.187386 & 3.458712 \\
\hline 6 & 81.47833 & 6.347081 & 5.787024 & 6.387566 & 59.32446 & 28.95953 & 8.210324 & 3.505689 \\
\hline 7 & 81.43021 & 6.366004 & 5.822033 & 6.381753 & 59.38043 & 28.91128 & 8.206267 & 3.502029 \\
\hline 8 & 81.29295 & 6.391133 & 5.841271 & 6.474648 & 59.33976 & 28.90241 & 8.223317 & 3.534503 \\
\hline 9 & 81.26033 & 6.384850 & 5.835845 & 6.518972 & 59.31359 & 28.89013 & 8.222265 & 3.574020 \\
\hline 10 & 81.25160 & 6.393017 & 5.836300 & 6.519083 & 59.31443 & 28.88245 & 8.219884 & 3.583237 \\
\hline & & & & & & \\
\hline & DLLTC & & & & & & \\
\hline & DLBCH & DLETH & DLLTC & XRP & DLBCH & DLETH & DLLTC & XRP \\
\hline 1 & 53.58326 & 16.58483 & 29.83191 & 0.000000 & 0.044176 & 4.639891 & 0.075287 & 95.24065 \\
\hline 2 & 60.12607 & 13.74233 & 26.13123 & 0.000364 & 18.74100 & 3.556617 & 26.84810 & 50.85429 \\
\hline 3 & 56.30680 & 16.07609 & 25.44681 & 2.170293 & 32.46620 & 8.357956 & 18.49702 & 40.67882 \\
\hline 4 & 55.50013 & 17.02827 & 25.12766 & 2.343948 & 32.49440 & 8.319747 & 18.47478 & 40.71108 \\
\hline 5 & 54.98961 & 17.69088 & 24.98045 & 2.339057 & 32.57102 & 8.352982 & 18.42857 & 40.64743 \\
\hline 6 & 55.00314 & 17.69766 & 24.96166 & 2.337539 & 32.57245 & 8.374638 & 18.44975 & 40.60317 \\
\hline 7 & 54.97689 & 17.68707 & 24.95845 & 2.377584 & 32.56303 & 8.381276 & 18.44626 & 40.60943 \\
\hline 8 & 54.95341 & 17.68109 & 24.95132 & 2.414185 & 32.56191 & 8.385634 & 18.44362 & 40.60884 \\
\hline 9 & 54.95119 & 17.67703 & 24.94348 & 2.428298 & 32.56536 & 8.387850 & 18.44204 & 40.60475 \\
\hline 10 & 54.95058 & 17.67907 & 24.94168 & 2.428670 & 32.56446 & 8.389392 & 18.44198 & 40.60416 \\
\hline &
\end{tabular}

Not: Tablodaki ilk sütunda zaman dönemleri, diğer sütunlarda ise her bir değişkenin hata varyansında meydana gelen değişime kendisinin ve diğer değişkenlerin etkilerini gösteren varyans ayrıştırma sonuçlarını göstermektedir.

Variance Decomposition ofDLBITCOIN_CASH

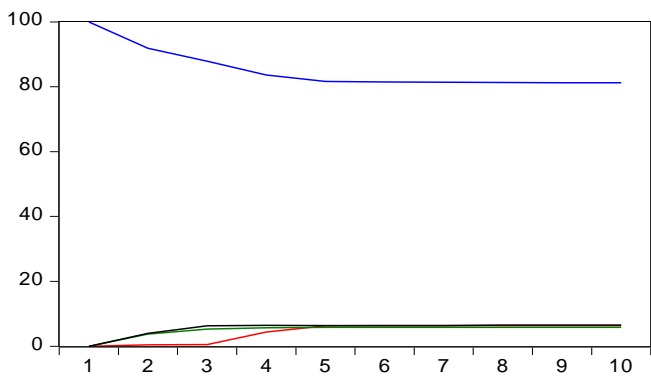

- DLBITCOIN_CASH DLETHEREUM DLLITECOIN $\longrightarrow$ XPR

Variance Decomposition of DLLITECOIN

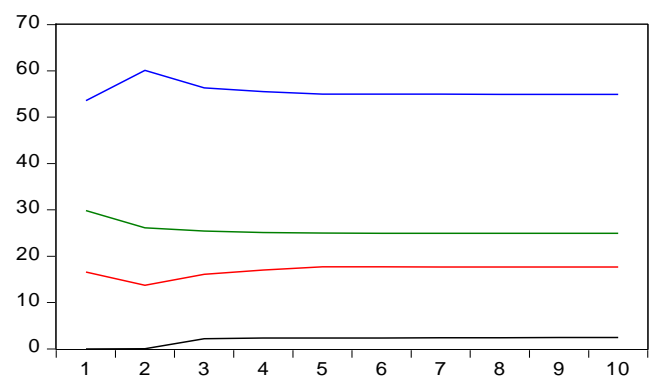

- DLBITCOIN_CASH D DLETHEREUM

Şekil.5. Varyans Ayrıştırmasının grafiksel gösterimi
Variance Decomposition of DLETHEREUM

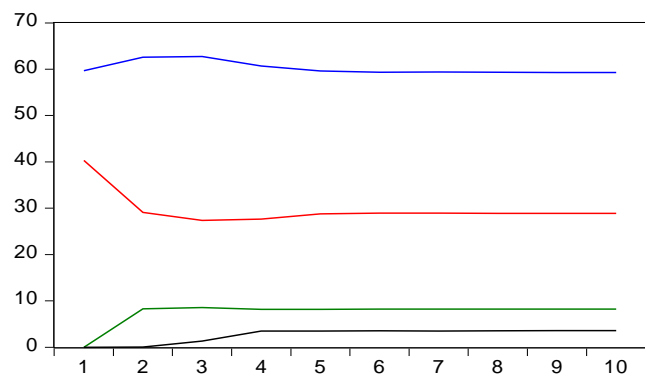

- DLBITCOIN_CASH
- DLETHEREUM
DLITECOIN

Variance Decomposition of XPR

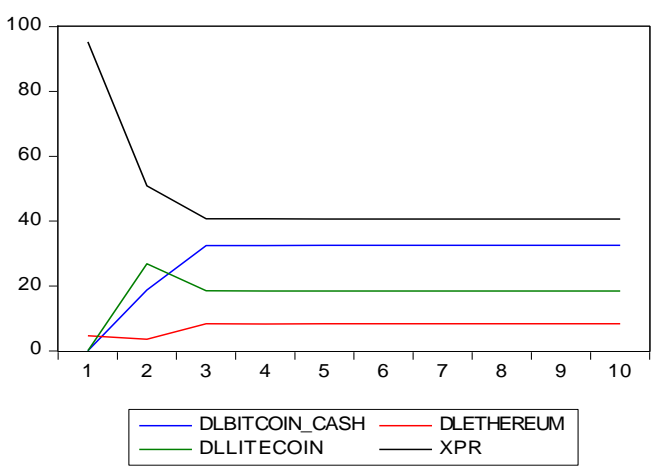




\section{V.SONUÇ}

$\mathrm{Bu}$ araştırma, 2017:3-2020:1 dönemleri arasında değişkenlerin aylık fiyat ortalamaları (USD cinsinden) göz önünde bulundurularak birbirlerinin fiyatlanmaları üzerindeki uzun veya kısa vadeli etkileşimlerini belirlemek amacıyla değerleri arasındaki ilişki analiz edilmiştir. Çalı̧̧mada, 10 dönem önceki verilere kadar fiyat ilişsisi analizi yapılmış olup elde edilen sonuçlar aşağıdaki gibidir:

- Serilerin logaritmaları alınarak elde edilen yeni değişkenlere yapılan birim kök testi neticesinde serilerin 3 tanesinin düzeyde durağan olmadıkları görülmüştür. Serileri durağan hale getirmek için serilerin 1. farkları alınmış ve 1. farklara birim kök testi uygulanmıştır. Bunun sonucunda tüm serilerin 1. farkta durağan hale geldikleri saptanmıştır.

- Vektör otoregresif modelin gecikme uzunluğunu belirlemek için AIC, SC, HQ bilgi kriterlerinden yardım alınmış ve $\% 5$ anlamlılık düzeyinde cimrilik prensibi gereği gecikme uzunluğu 1 alınmıştır fakat sabit varyans varsayımını sağlamadığından dolayı gecikme uzunluğu 2 alınmıştır. Varsayımların 2 gecikme uzunluğunda sağlandığı tespit edilmiştir.

- Varyans ayrıştırması sonuçlarına göre;

I. Bitcoin Cash'in hata varyansında birinci dönemde meydana gelen değişimin bütünü kendisinden kaynaklanmaktadır. İkinci dönemde değişimin \%91,87'si kendisinden, $\% 0,45$ 'i Ethereum'dan, \%3,71'i Litecoin'den ve $\% 3,94$ 'ü Ripple tarafindan açıklanmaktadır. Son dönemde ise standart sapmadaki değişimin $\% 81,25$ 'i kendisi tarafından açıklanmaya devam ederken; $\% 6,39$ 'u Ethereum, \%5,83'ü Litecoin ve $\% 6,51$ 'i Ripple tarafindan açıklanmaktadır. Kisacası Bitcoin Cash'in hata varyansını açıklamada Ethereum, Litecoin ve Ripple'ın etkisinin zamanla arttığı ve kendi etkisinin ise zamanla azaldığı sonucuna varılmıştır.

II. Ethereum'un hata varyansının ilk dönemde \%59,68'i Bitcoin Cash tarafindan, \%40,31'i kendisi tarafından açıklanmaktadır. Sonraki dönemlerde kendisi tarafindan açıklanma yüzdesi düşerken, Bitcoin Cash tarafindan açıklanma yüzdesi 2 . ve 3 . dönemlerde arttıktan sonra 4. dönemde bir düşüs sonrası 5 . dönemle birlikte yatay bir seyir izlemeye başlamıştır. 1. dönemde Ethereum'un hata varyansını açıklamada Litecoin'in etkisi yokken 2 . dönemde $\% 8$ 'e yükselmiş ve daha sonra son döneme kadar o da \%8 civarında yatay bir seyir izlemiştir. Ethereum'un hata varyansını açıklamada Ripple'ın ise diğerlerine oranla daha sınırlı bir düzeyde kaldığı görülmektedir.

III. Litecoin açısından bakıldığında, varyans ayrıştırma sonuçları yüksek oranda Bitcoin
Cash'in etkisine ve Bitcoin Cash'e nispeten az olmakla birlikte yine kendisine göre yüksek oranda Ethereum'un etkisini göstermektedir. Çünkü 10. döneme gelindiğinde Litecoin'in hata varyansının \%24,94'ü kendi, \%17,67'si Ethereum ve \%54,95'i Bitcoin Cash tarafindan açıklanmaktadır.

IV. Ripple'ın hata varyansının ise yine büyük bir bölümünün Bitcoin Cash tarafindan açıklandığı görülmektedir. Son dönemde Ripple hata varyansının \%32,56's1 Bitcoin Cash, \%8,38'i Ethereum, \%18,44'ü Litecoin ve $\% 40,60$ '1 kendisi tarafindan açıklanmaktadır.

- Birinci farkları alınarak durağanlaştırılan serilere $\% 5$ anlamlılık düzeyinde ikili gruplar halinde seçilen değişkenlere Granger nedensellik analizi testi uygulanmış ve değişkenler arasında; "BCH fiyatının, ETH'nin Granger nedeni olduğu", "BCH fiyatının, LTC fiyatının Granger nedeni olduğu", "BCH fiyatının, XRP fiyatının Granger nedeni olduğu", "LTC fiyatının, ETH fiyatının Granger nedeni olduğu", "ETH fiyatının, XRP fiyatının Granger nedeni olduğu", "LTC fiyatının, XRP fiyatının Granger nedeni olduğu" sonuçlarına ulaşılmıştır.

Alternatif bir yatırım aracı olarak kabul edilen dijital paralar ile birikimlerini değerlendirmek isteyen yatırımcıların, kriptoparaların fiyatlanmasında birbirleriyle olan ilişkilerini mutlaka dikkate almaları gerekmektedir. Yatırımcılar, yatırım sepetlerini oluştururken riskleri azaltmak için birbirleriyle nedensellik ilişkisi içinde olan kriptoparaları aynı sepete dâhil etmemeye özen göstermelidirler. $\mathrm{Bu}$ sayede mevcut riskleri en aza indirgeyerek tasarruflarını arttırma şansı yakalayabilirler. Binlerce kriptopara biriminin olduğu bir ekosistemden sınırlı sayıda kriptopara seçilerek yapılan bu çalışma, bu yönüyle çeşitli kısıtlamalara haizdir. Gelecek araştırmalarda çok daha fazla miktarda kriptopara birimi kullanılarak daha genel sonuçlar elde edilebilir.

\section{KAYNAKÇA}

[1] Abaan, E.D. (1997). Para: Teorik Bir Tarama ve Tartışma. Ankara: Türkiye Cumhuriyet Merkez Bankası İdare Merkezi.

[2] Atik, M., Köse, Y., Yılmaz, B., \& Sağlam, F. (2015). Kripto Para: Bitcoin ve Döviz Kurları Üzerine Etkileri. Bartın Üniversitesi İ.İ.B.F. Dergisi, 6(11), 247-261.

[3] Barışık, S., \& Kesikoğlu, F. (2015, Şubat 6). Türkiye'de Bütçe Açıklarının Temel Makroekonomik Değişkenler Üzerine Etkisi. Ankara Üniversitesi SBF Dergisi, 67.

[4] Baur, D.G., \& Dimpfl, T. (2017). Excess Volatility as an Impediment for a Digital Currency (https://papers.ssrn.com/sol3/papers.cfm?abstract_id= 2949754). [26.02.2021].

[5] Briere, M., Oosterlinck, K., \& Szafarz, A. (2015). 
Virtual currency, tangible return: Portfolio diversification with Bitcoin, Journal of Asset Management, 16(6), 365-373.

[6] Ciaian, P., Rajcaniova, M., \& Kancs, D. (2018). Virtual Relationships: Short and Long Run

[7] Evidence from Bitcoin and Altcoin Markets. Journal of International Financial Markets, Institutions and Money, 52, 173-195.

[8] Çakın, M. (2019). Kripto Paralar: Bitcoin, Döviz Kurları ve Alternatif Kripto Paralar Arasındaki İlişkinin İncelenmesi, Dokuz Eylül Üniversitesi Sosyal Bilimler Enstitüsü, İşletme Bölümü, Bitirme Tezi, İzmir.

[9] Çeker, S.M. (2018). Kripto Paralar ve Ekonomik Etkileri, Yıldız Teknik Üniversitesi İktisadi ve İdari Bilimler Fakültesi İktisat Bölümü, Bitirme Tezi, İstanbul.

[10] Enders, W. (1995). Applied Econometric Time Series. New York: John Wiley and Sons Inc.

[11] İçellioğlu, C. S., \& Öztürk, M. B. E. (2017). Bitcoin ile seçili döviz kurları arasındaki ilişkinin araştırılması: 2013-2017 dönemi için johansen testi ve granger nedensellik testi, Maliye ve Finans Yazıları, 109, 51-70.

[12] Granger, C. W. J. (1969). Investigating Causal Relations by Econometric Models and Cross-Spectral Methods. Econometrica. 37(3): 431.

[13] Gujarati, D. (2003). Basic Econometrics. New York: McGraw-Hill Education.

[14] Kajtazi, A., \& Moro, A. (2017). Bitcoin, portfolio diversification and Chinese financial markets (https://papers.ssrn.com/sol3/papers.cfm?abstract_id= 3062064). [26.02.2021].

[15] Karaağaç, G. A., \& Altınırmak, S. (2018). En yüksek piyasa değerine sahip on kripto paranın birbirleriyle etkileşimi. Muhasebe ve Finansman Dergisi, 79, 123-138.

[16] Karaoğlan, S., Arar, T., \& Bilgin, O. (2018). Türkiye'de kripto para farkındalığı ve kripto para kabul eden işletmelerin motivasyonları, İşletme ve İktisat Çalışmaları Dergisi C. 6, S. 2, 15-28.

[17] Konuşkan, A., Teket, T., Ömürbek, V., \& Bekçi, İ. (2019). Kripto Paraların Fiyatları Arasındaki İlişkinin Tespitine Yönelik Bir Araştırma. Süleyman Demirel Üniversitesi İktisadi ve İdari Bilimler Fakültesi Dergisi C. 24, S. 2, 317.

[18] Lütkepohl, H., \& Kratzig, M. (2004). Applied Time Series Econometrics. New York: Cambridge University Press.

[19] Özgen, F. B., \& Güloğlu, B. (2004). Türkiye'de İç Borçların İktisadi Etkilerinin VAR Tekniğiyle Analizi. ODTÜ Gelişme Dergisi, 95-96.

[20] Sever, E., \& Demir, M. (2007). Türkiye'de Bütçe Açı̆̆ı ile Cari Açık Arasındaki İlişkilerin VAR Analizi ile İncelenmesi. Eskişehir Osmangazi Üniversitesi İ̈BF Dergisi, 54-55.

[21] Sevüktekin, M., \& Çınar, M. (2017). Ekonomik Zaman Serileri Analizi. Bursa: Dora Yayıncilık.

[22] Sims, C. A. (1980). "Macroeconomics and Reality", Econometrica, 48, 1-49.

[23] Temizer, A., \& Serbestoğlu, İ. (2018). Kripto Paralarda Getiri ve İşlem Hacmi Arasındaki Nedensellik İlişkisi Üzerine Ampirik Bir İnceleme, Multidisipliner Çalışmalar-4 (Sosyal Bilimler), c. 1.

[24] Turgan, S. G. (2008). Temel Getiri Araçları Arasındaki İlişkinin Ekonometrik Analizi: Türkiye Örneği. DergiPark Akademik, 219.

[25] Ulusoy, T. (2011). Financial power analysis of countries: Transmitters (adsorbents), setters and unresistants. African Journal of Business Management, 5(22), 9087-9105. 